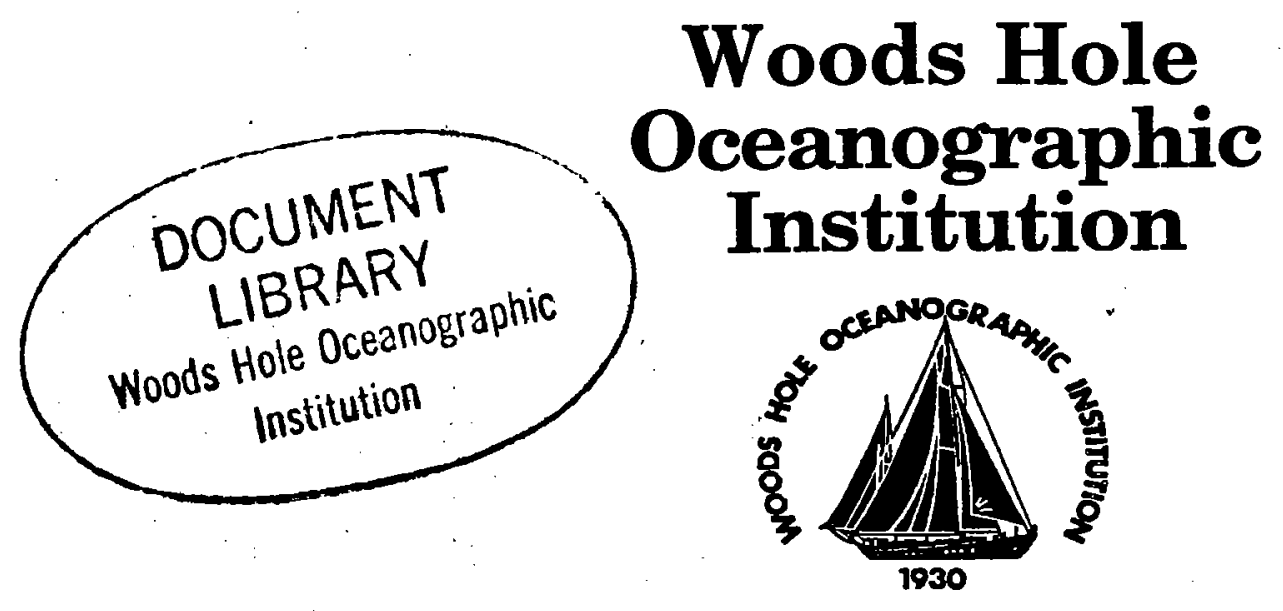

Hurricane Impacts on the Caribbean

Coastal/Marine Environment:

Using Scientific Assessment to Plan for the Future

by

D.G. Aubrey, G.S. Giese, D.M. Burdick, M.T. Agardy,

J.C. Haney and F.J. Gable

September 1991

Funding was provided by the Andrew W. Mellon Foundation to the Coastal Research Center of the Woods Hole Oceanographic Institution (WHOI) and the NOAA National Sea Grant College Program Office,

Department of Commerce, under Grant No. NA86-AA-D-90.

Approved for public release; distribution unlimited.

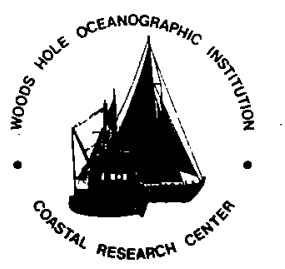

CRC-91-02

Coastal Research Center 


\title{
Hurricane Impacts on the Caribbean Coastal/Marine Environment: Using Scientific Assessment to Plan for the Future
}

\author{
by
}

\author{
D.G. Aubrey, G.S. Giese, D.M. Burdick, M.T. Agardy, \\ J.C. Haney and F.J. Gable \\ Woods Hole Oceanographic Institution \\ Woods Hole, Massachusetts 02543
}

September 1991

\section{Technical Report}

Funding was provided by the Andrew W. Mellon Foundation to the Coastal Research Center of the Woods Hole Oceanographic Institution (WHOI) and the NOAA National Sea Grant College Program Office, Department of Commerce, under Grant No. NA86-AA-D-90.

Reproduction in whole or in part is permitted for any purpose of the United States Government. This report should be cited as Woods Hole Oceanographic Inst. Tech. Rept., WHOI-91-40, CRC-91-02.

Approved for public release; distribution unlimited.

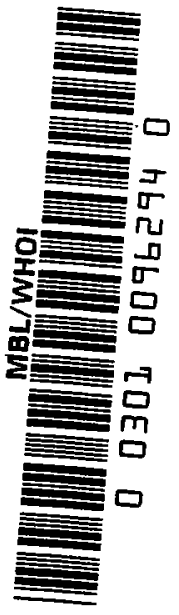

\section{Approved for Distribution:}

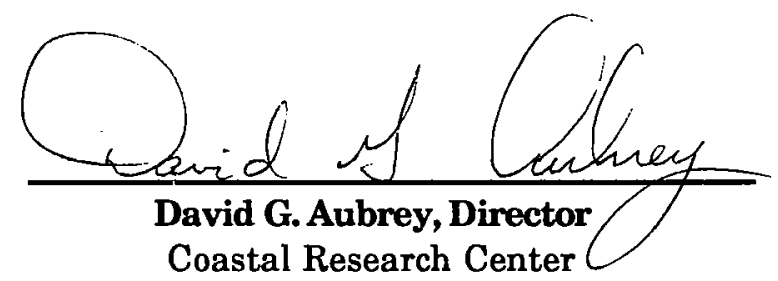




\section{Table of Contents}

$\begin{array}{ll}\text { Abstract } & 1\end{array}$

$\begin{array}{lll}1.0 & \text { Executive Summary } & 1\end{array}$

1.1 Research Scope $\quad 2$

2.0 Hurricane Hugo $\quad 3$

2.1 Hugo's Meteorological Statistics $\quad 4$

3.0 Trip Reports: $\quad 6$

3.10 Hurricane Hugo-Related Impacts on the Marine Ecosystems of the Antilles 6

$\begin{array}{lll}3.11 & \text { Summary } & 6\end{array}$

3.12 St. Thomas $\quad 6$

3.13 St. John $\quad 9$

3.14 St. Croix $\quad 9$

3.15 Puerto Rico $\quad 9$

3.20 Effect of Hurricane Hugo and Subsequent Recovery of Coastal Landforms and Plant Communities of St. Croix, U.S.V.I. 13

3.21 Introduction $\quad 13$

3.22 - Field Study and-Data Analysis Methods 13

3.23 Results and Discussion: - $\quad 14$

3.231 North Shore: Shoy's Beach $\quad 14$.

3.232 South Shore: Halfpenny Bay 19

3.24 Site Comparisons and General Observations 24

3.25 Recommendations $\quad 26$

3.26 Conclusions $\quad 27$

3.30 Interim Progress Report on 1989 Rapid Response-Hurricane Hugo Project: "Impact of Hurricane Hugo on Endangered Species of Marine and Endemic Forest Birds in the Lesser Antilles"

$\begin{array}{llr}3.31 & \text { Introduction } & 29\end{array}$

3.32 Principal Findings and Concerns $\quad 29$

3.33 Implications and Recommendations for Future Research $\quad 29$

3.34 Some Initial Effects of Hurricane Hugo on Endangered and Endemic Species of West Indian Birds $\quad 30$

4.0 Relevant Virgin Islands General Coastal Program Elements 32

4.10 Some Institutional Adjustments/Responses 33 
5.0 An Example of Storm Defense Adjustments/Responses For Use by the Virgin Islands Government

6.0 Summary For the Virgin Islands--Institutional Responses and Socio-economic Modelling

7.0 Processes and Management in the Coastal Zone: An Overview 40

7.10 Physical Processes in the Coastal Zone $\quad 41$

7.11 Surface Gravity Waves $\quad 42$

7.12 Quasi-steady Currents (Winds, Tides and Wave-induced) 42

7.13 Sedimentation Processes $\quad 43$

7.20 Interaction of Physical Forcing and Morphology of Coasts 43

7.30 Physical Stresses on Coasts: Natural and Anthropogenic 44

$\begin{array}{lll}7.40 & \text { Management } & 44\end{array}$

7.50 Biological and Chemical Interactions With Physical Processes 45

7.60 Management of Coastal Resources $\quad 45$

$\begin{array}{ll}\text { Further Reading } & 47\end{array}$ 


\title{
HURRICANE IMPACTS ON THE CARIBBEAN COASTAL/MARINE ENVIRONMENT: USING SCIENTIFIC ASSESSMENT TO PLAN FOR THE FUTURE
}

by

\author{
D. G. Aubrey, G. S. Giese, D. M. Burdick ${ }^{1}$, \\ M. T. Agardy' ${ }^{2}$ J. C. Haney ${ }^{3}$, and F. J. Gable \\ Coastal Research Center \\ Woods Hole Oceanographic Institution \\ Woods Hole, Massachusetts 02543 USA
}

\begin{abstract}
The passage of Hurricane Hugo through the eastern Caribbean provided a unique opportunity for multidisciplinary study of (1) the effects of severe storms on tropical coastal and marine ecosystems, and (2) the physical and biological responses of those ecosystems to intense storm-induced changes. In addition to its direct value as basic science, this study can be used to facilitate development of improved coastal and marine resource management capabilities.
\end{abstract}

\subsection{Executive Summary}

Hurricane Hugo wreaked havoc on coastal and marine ecosystems in the Caribbean; some of the damage will persist for years to come. Although hurricanes and tropical storms are natural episodic events, impacts from recent hurricanes may have been exacerbated by poorly planned development, previously stressed coastal ecosystems, and careless recovery efforts. Since some global climate models project future increases in both the frequency and severity of tropical storms and hurricanes, it is time that we learn from our past experiences to brace for the future.

Cross-comparison with data from other major hurricanes (including Gilbert and Allen) will allow us to generate a larger and more meaningful data set. We wish to test two hypotheses: 1) that marine ecosystem structure is shaped by severe episodic events, 2) that the impact from these events is accentuated when ecosystem stress causes pre-existing degradation of the coastal environment. The information garnered from this research will allow us to develop models which forecast large-scale ecosystem effects from tropical storms. The testing of the hypotheses and data analyses/model generation will require careful ecological and physical measurements of impact and recovery across many scales of ecosystem structure. A multi-disciplinary effort is required to

\footnotetext{
1 Jackson Estuarine Lab, University of New Hampshire

2 World Wildlife Fund,US Washington D.C.

${ }^{3}$ Marine Policy Center, WHOI
} 
achieve such a comprehensive assessment. The ultimate objective is to determine the relationship between episodic events and the structure of marine ecosystems in order to provide guidance for use and management of marine resources.

\subsection{Research Scope}

Marine and terrestrial ecosystems respond to environmental conditions on a variety of temporal and spatial scales. Tropical ecosystems generally evolve gradually and under conditions that include episodic disturbances. Occasionally, however, severe episodic events impact these systems and cause massive structural damage and impaired ecosystem functioning. A fine line exists between what can be considered normal episodic disturbance and atypical, prolonged disturbance and stress. The latter may be occurring more frequently as tropical storms increase in their intensity and make landfall on overdeveloped, acutely stressed coastal environments.

Due to the recent (1989) passage of Hurricane Hugo in the Lesser Antilles, and the earlier (1988) passage of Hurricane Gilbert in the western and central Caribbean, we have the opportunity to compare the impacts of severe storms on similar but geographically isolated habitats. More importantly, we have had the opportunity to examine impact, response, and recovery in areas that have been degraded by man's activities and compare those to more pristine and undisturbed areas. All of these opportunities increase the utility of this research for designing and implementing wise coastal management.

The scientific work focuses on the abiotic components of the environment and the physical processes that maintain the ecosystem, the biotic components that contribute to the trophic structure and biodiversity in different habitats, and the linkages between the physical and biological components of coastal systems. Important habitats in the tropical coastal landscape, including coral reefs, seagrass beds, sandy lagoons, mangrove systems, coastal ponds, and shorelines, have all acted as focal points for the assessment. Assessments include an inventory of physical damage to the terrestrial and marine portions of the coastal zone, an analysis of the extent to which physical biological processes have been altered by storm impact, and the generation of information allowing quantitative and qualitative modelling of storm surge, wave impact and uprush, wind impact, and population dynamics. The synthesis of information from affected areas has been facilitated by our own rapid response work and the large quantities of data generated by local scientists.

A major portion of our work has focused on translating scientific results into information useful to the regulatory sector. Effective risk assessment and management of tropical ecosystems is often hampered by poor scientific understanding. Even where good scientific information exists, it is often not made available to policy-makers and thus cannot be used as a basis for formulating effective management. 


\subsection{Hurricane Hugo}

Hurricane Hugo, in 1989 was the strongest storm to strike the Caribbean since Hurricane Gilbert in 1988, and both caused much damage. The total property loss was more than $\$ 10$ billion dollars with more than $\$ 7$ billion of that in the continental United States and the remainder in the northeastern Caribbean. The total loss of life was 28 in the Caribbean and 21 in the continental United States, remarkably low considering the widespread destruction.

The total number of deaths associated with Hugo in the Caribbean is estimated as follows:

$\begin{array}{lc}\text { Antigua and Barbuda } & 1 \\ \text { Guadeloupe } & 11 \\ \text { Montserrat } & 10 \\ \text { St. Kitts and Nevis } & 1 \\ \text { Puerto Rico } & 2 \\ \text { U.S.Virgin Islands } & 3\end{array}$

On September $15^{\text {th }}$ Hurricane Hugo was a category 5 hurricane, the strongest category, with a Mean Sea Level Pressure (MSLP) of $918 \mathrm{mb}$ and an estimated maximum sustained surface wind speed of 160 miles h$^{-1}(72 \mathrm{~m} / \mathrm{s})$ prior to entering the Caribbean. Fortunately, the hurricane weakened to a category- 4 hurricane before entering the Caribbean.

A hurricane watch was first issued for the northeastern Caribbean islands from St. Lucia through St. Martin and the British Virgin Islands on the evening of September 15. Later that day, hurricane warnings were issued, and on the following day were extended to include Puerto Rico and the U.S. Virgin Islands. This meant that well over 24 hours of warning were provided prior to the center moving into the eastern Caribbean in the late evening and early morning hours of September 17 and 18. Response in the region was excellent based upon the relatively low loss of life from this category-4 hurricane which produced between \$2-3 billion in damage in the region. This effective warning and response system was not something that just happened when Hugo appeared. It was the result of years of cooperative work by governments in the region.

The 1989 season was characterized as a Cape Verde (African) hurricane year in which seven of the tropical cyclones were named near those islands and then tracked westward across the Atlantic. The season had 11 named storms, seven of which acquired hurricane intensity. This compares to the past 50-year average of 9.5 tropical storms, of which 5.5 became hurricanes. Africa contributed $100 \%$ to the total number of storms during 1989, indicating the highly tropical characteristics of the 1989 hurricane season. This equals the value for 1979 when the Cape Verde- 
type hurricanes David and Frederic occurred. Typically, Africa is the main source of storms for the Atlantic basin.

The Hurricane Destruction Potential (HDP) is a measure of a hurricane's potential for wind and storm surge destruction. It is defined as the sum of the square of each hurricane's maximum winds for each six-hour period of its existence. The average HDP during African years of the 1967-89 period was larger than the average HDP of the non-African years. This continues to lend credence to the idea that usually the most intense hurricanes are spawned by African waves, thus underlining the importance of monitoring such waves.

\subsection{Hugo's Meteorological Statistics}

A reconnaissance aircraft reaching Hurricane Hugo, while it was in the Atlantic east of the Antilles, reported a central pressure of $918 \mathrm{mb}$, a wind speed of $85 \mathrm{~m} \mathrm{~s}^{-1}$ at an altitude of $500 \mathrm{~m}$ and a surface wind speed of $72 \mathrm{~m} \mathrm{~s}^{-1}$. This turned out to be Hugo's maximum intensity and designated the cyclone as a category five hurricane.

On September 17th, just before Hugo's eye passed over Guadeloupe, an aircraft reported a wind speed of $70 \mathrm{~m} \mathrm{~s}^{-1}$ at $700 \mathrm{mb}$. A surface pressure of 941.4 millibars has since been reported from Guadeloupe (Table 1). It is estimated that the hurricane's maximum 1-min surface wind had decreased to $62 \mathrm{~m} \mathrm{~s}^{-1}$ at this time. The maximum surface wind was again estimated at $62 \mathrm{~m} \mathrm{~s}^{-1}$ when the eye passed over St. Croix at 0600 GMT on the $18^{\text {th }}$. Few direct tide gauge measurements of the storm surge water levels have been received, however. 
Table 1. Hurricane Hugo-selected surface observations, September 1989.

\begin{tabular}{|c|c|c|c|c|c|c|c|}
\hline & \multicolumn{2}{|c|}{$\begin{array}{l}\text { Minimum sea-level } \\
\text { pressure }\end{array}$} & \multicolumn{3}{|c|}{$\begin{array}{l}\text { Maximum surface wind speed } \\
\qquad\left(\mathrm{m} \mathrm{s}^{-1}\right)\end{array}$} & \multirow{2}{*}{$\begin{array}{l}\text { Storm surge } \\
\text { (tide height } \\
\text { above normal) }\end{array}$} & \multirow{2}{*}{$\begin{array}{l}\text { Rain } \\
\text { (storm } \\
\text { total) } \\
(\mathrm{mm})\end{array}$} \\
\hline & $\begin{array}{c}\text { Pressure } \\
(\mathrm{mb})\end{array}$ & $\begin{array}{c}\text { Date/time } \\
\text { (UTC) }\end{array}$ & $\begin{array}{l}\text { 1-minute } \\
\text { average }\end{array}$ & $\begin{array}{c}\text { Peak } \\
\text { gust }\end{array}$ & $\begin{array}{c}\text { Date/time } \\
\text { (UTC)* }\end{array}$ & & \\
\hline Guadeloupe & 941.1 & & & & & & \\
\hline \multicolumn{8}{|l|}{ St. Maarten } \\
\hline Juliana Airport & & & 21 & 35 & $18 / 0200$ & & \\
\hline \multicolumn{8}{|l|}{ Puerto Rico } \\
\hline Gurabo & & & & & & & 234 \\
\hline Isla de Culebra & & & & 76 & & & \\
\hline Isla Verde & 970.3 & $13 / 1415$ & & & & & \\
\hline Luquillo & 956 & $18 / 1300$ & & & & & \\
\hline Roosevelt Roads & Is 946.1 & $18 / 1250$ & 46 & 54 & $18 / 1158$ & & \\
\hline San Juan & 970.3 & $18 / 1444$ & 35 & 41 & $18 / 1350$ & & 76 \\
\hline
\end{tabular}




\subsection{Trip Reports:}

\subsection{Hurricane Hugo-Related Impacts on the Marine Ecosystems of the Antilles (M. T. Agardy)}

\subsection{Summary}

This report summarizes a preliminary survey of Hurricane Hugo-induced impacts on the marine and coastal ecosystems of several Caribbean islands. The damaged sites were visited during 15-25 November, 1989, roughly two months after the hurricane ravaged the islands. Wherever possible, surveying included photography (aerial and conventional), snorkeling and SCUBA diving observation, and sampling.

The most prominent impacts on the coastal ecosystem observed were breakage of corals (especially Acropora species), abrasion of stony corals by sand-laden currents, siltation and sedimentation of reefs and seagrass beds, widespread and catastrophic destruction of seagrass beds through the creation of new blow-outs, "uprooting" of macroalgae, gorgonians, and sponges, mangrove deforestation, and physical damage to all coastal habitats from debris. Secondary effects included oil spill damage (St. Croix), sewage-related nutrient loading (St. Croix) and environmental damage from reconstruction/recovery efforts (throughout the impacted area). Government ministers and local scientists are aware of the primary and secondary impacts, but appear to be completely overloaded in post-hurricane work and unable to initiate scientific studies or monitoring programs. Furthermore, no regional efforts to study hurricane impacts have been undertaken.

\subsection{St. Thomas}

St. Thomas was spared much of the destruction befalling her neighboring islands. Roofs were damaged in some areas; resorts near the water had structural damage (Table 2). Interestingly, most of the terrestrial damage occurred in the lee of the island on the north side. The boating community was hardest hit, with wrecked yachts and pleasure boats lining the shore along virtually the entire south and east coasts. Sand erosion occurred at Frenchman's Reef at the entrance to Charlotte Amalie Harbour, and at Bolongo and Cowpet Bays. Mangroves were impacted at the Mangrove Lagoon. Coral reefs show some signs of siltation, especially in the northeast portion of the main island and some of the offshore cays. Soft corals and sponges were uprooted and have washed ashore at nearly all the beaches; some seagrass beds have also been damaged. The V.I. Division of Fish and Wildlife (DFW) is particularly interested in quantifying the impact of seagrass destruction on fisheries and conch fisheries (Map 1). 


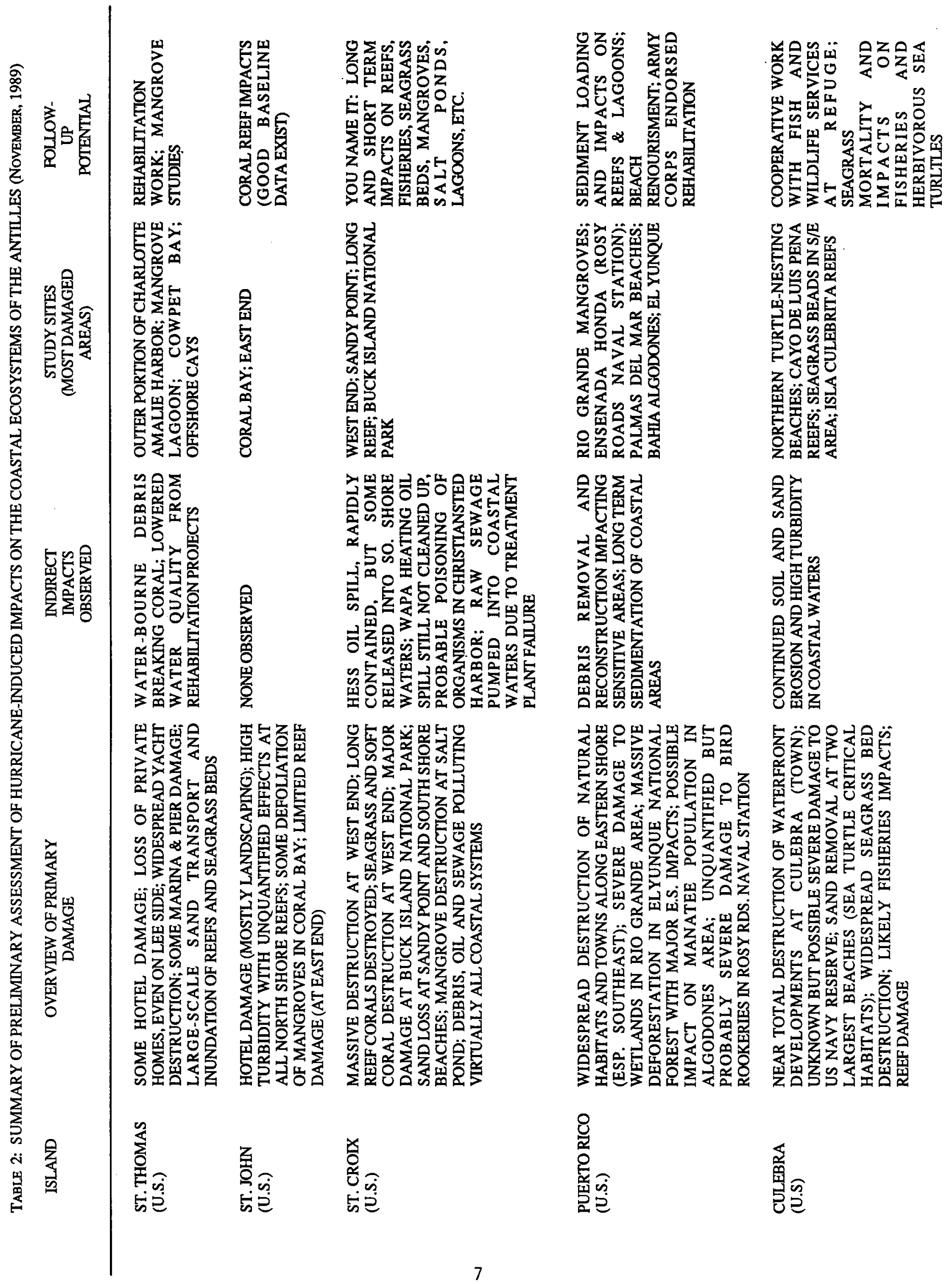









\subsection{St. John}

Despite rumors to the contrary, many of the coral reefs within the boundary of the St. John National Park were not adversely affected by Hugo. Turbidity continues to be high from sediment loading. Mangroves were affected in the Coral Bay area, but impact does not seem to be long term. Water-borne debris continues to persist and may cause substantial post-hurricane damage to corals.

\subsection{St. Croix}

St. Croix was devastated by the hurricane, and has barely recovered in the time since. Virtually every habitat was affected, some severely. Primary damage included reef breakage and siltation at Long Reef, Buck Island Reef, and Green Cay; mangrove and other tree deforestation on the west end; damage to the Sandy Point Salt Pond; sand erosion on south shore beaches; and massive seagrass bed destruction. Secondary impacts include oil spill damage from the Hess Oil and WAPA spills; eutrophication from the dumping of untreated sewage; and debris damage. Wind-borne sand deposits in inland areas measure up to a meter in depth. Evidence of seagrass bed and soft coral destruction exists in the stormline at Sandy Point; dead sponges, sea fans, and gorgonians exceed 30 individuals per meter of tideline.

Although good baseline data on coral reef and coastal habitats exist for many parts of the island, further work in St. Croix will be complicated by the general condition of the island. Map 2 shows areas of major impact.

\subsection{Puerto Rico}

Puerto Rico can boast of having the most systematic surveys of damage to the coastal environment, although their efforts are directed primarily towards endangered species and not to coastal systems in general. On mainland Puerto Rico, Hugo caused most damage to the eastern and northeastern portions of the island. Extensive defoliation and deforestation of mangrove wetlands in the Rio Grande area is visible by air. Ground surveys along the eastern shore point to erosion of some of the major resort area beaches. Similar impacts are likely to have occurred in the Roosevelt Roads Naval Station (Rosy Roads), which is not open to the public but which got a much more direct hit by Hugo. The Rosy Roads area is critical habitat for many bird species, and Department of Natural Resources (DNR) scientists will be trying to assess damage to avifauna in the coming months. They will also investigate the impact of Hugo on critical habitats for the West Indian manatee, an endangered species found in coastal areas to the southeast. Utilities have been restored in the damaged areas, and rental cars and hotel rooms are easy to obtain. Map 3 shows sites of major damage. 
The two small islands to the east of Puerto Rico, Culebra and Vieques, received the brunt of the storm damage. Ninety percent of the homes on the island were severely damaged or destroyed. Seagrass beds around the island of Culebra were obliterated, complicating local efforts to promote the recovery of the green turtle (Chelonia mydas) there. Sea turtle nesting beaches were only slightly damaged, and new beaches were formed by some of the displaced sand. Ecosystem damage on these two islands is continuing and is exacerbated by unregulated reconstruction activities. 
3.20 Effect of Hurricane Hugo and Subsequent Recovery of Coastal Landforms and Plant Communities on St. Croix, U. S. V. I. (David M. Burdick \& Graham S. Giese)

\subsection{Introduction}

Barrier beaches serve an important protective function for shoreward ecosystems and societal infrastructure through dissipation of storm wave energy and as barriers to storm-elevated sea levels. Plant communities are intimately connected with both the development of barrier landforms and their effectiveness as storm buffers. The structures (types of plants, e. g., grasses, shrubs), composition (species abundances) and distribution of coastal plant communities are largely controlled by elevation and hydrology, substrata composition, and exposure to wind and salt. Because of their position and role in shoreline protection, these systems often bear the brunt of the storm's energy and exhibit dramatic storm impacts. However, despite the importance of these plant communities to the development and maintenance of coastal barrier systems, little is known about their post-storm recovery strategies.

We have completed two post-storm surveys that examined the response to Hurricane Hugo of barrier beaches and their plant communities on St. Croix, U. S. Virgin Islands. Most of our effort was devoted to the detailed description of two barrier beach systems, Shoy's Beach on the north coast and Halfpenny Bay beach on the south coast of the island. Our objectives were: (1) to quantify the impacts of Hurricane Hugo on the landforms and vegetative communities of these barrier beaches, and (2) to conduct a preliminary assessment of the recovery rates and processes of the landforms and vegetation, and the relationships between landforms and plant communities during the recovery process.

\subsection{Field Study and Data Analysis Methods}

Our work took place during the periods January 7-20 and November 9-15, 1990. In addition to our detailed study of the two barrier beach systems, Shoy's and Halfpenny Bay, we conducted a generalized island-wide survey of hurricane impacts on the beaches and shore vegetation of St. Croix, covering approximately 80 percent of the island's coastline. In January, we made a very limited one-day survey of impacts on selected beaches on St. Thomas. In November, we consulted with the Island Resources Foundation on St. Thomas, and provided this group with various data of hurricane impact on St. Croix sites from January and November, 1990.

To provide a frame of reference for observations at the Shoy's Beach and Halfpenny Bay sites, we made three transects at each location. The barrier beach systems were typically composed of three parts: beach, dune and swamp. Quantitative measurements of barrier beach profiles and plant communities were made using standard survey and plant quadrat methods $\left(1 \mathrm{~m}^{2}\right.$ quadrats, 
stratified randomized design with communities as blocks). Sand deposited during and following the storm was warmer in hue (pinkish or brownish) than older sand deposits (white to grey). The depth of new sand deposits were determined at all vegetation quadrats. Trees that had fallen prior to the storm were recognized by their advanced state of decomposition if they had died, and by the reorientation of their branches if they had remained alive. Differences between communities, sites and dates were tested using analysis of variance (ANOVA) and t-tests.

Pre- and post-storm aerial surveys of our detailed study sites were used to estimate shoreline erosion. Aerial photographs were taken at a scale of 1:9600 in March, 1988 and again in September, 1989, five days after the storm. Changes in position of the vegetation line (dune scarp) normal to the shore were measured from transparencies. In addition, an independent estimate of shoreline erosion was obtained in January by measuring the distance from the new dune scarp seaward to the edge of where intact plant roots were protruding from the new beach sand.

\subsection{Results and Discussion:}

\subsection{North Shore: Shoy's Beach}

Dune retreat amounted to approximately 20 feet, as estimated from field observations as well as from aerial photography (Table 3). Low areas of the dune line were overwashed by the storm surge, resulting in new sand deposits that increased the surface elevation of the dunes by up to 1.4 feet. Overwash fans extended more than 100 feet from the dune scarp into the back-barrier mangrove swamp (Figure 1).

Table 3. Estimates of beach retreat rates (mean distance in feet $+/$ - standard error) at Shoy's Beach and Halfpenny Bay beach based on aerial photography $(n=20)$ and direct measurement from the seaward edge of the protruding roots (old dune scarp) to the new dune scarp $(n=3)$.

METHOD SHOY'S BEACH HALFPENNY BAY

Aerial photography

Root line to dune scarp
$21.0+/-2.0$

$19.7+/-1.7$
$33.8+/-3.6$

$32.3+/-0.3$ 


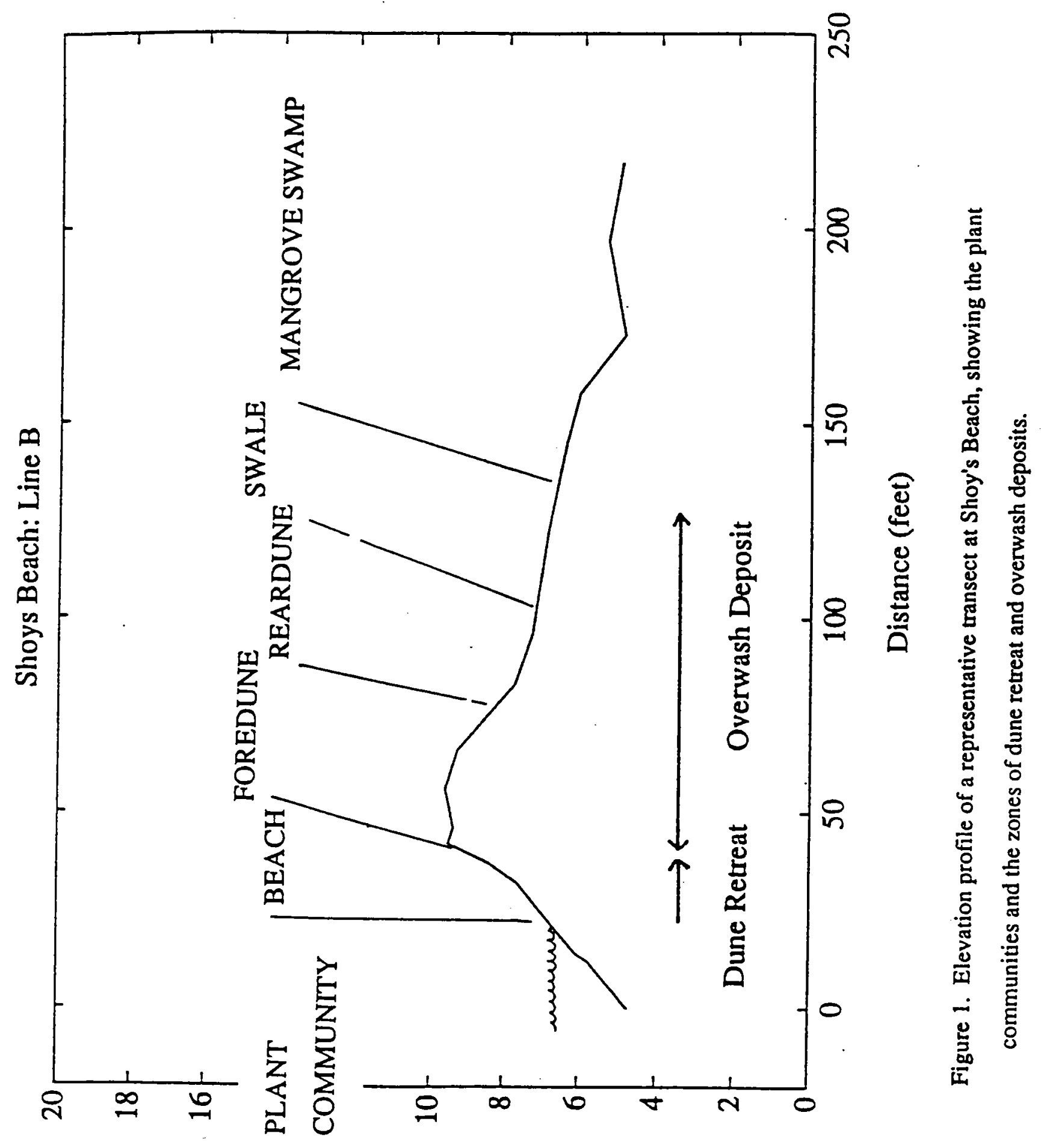

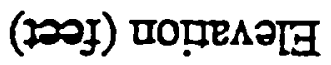


Plant communities included a pioneer community on the back shore consisting of grasses and vines; foredune and backdune communities dominated by grasses, shrubs and trees; a swale community of grasses and sedges; and a mangrove swamp community (Figure 1).

Although sheltered from the brunt of the storm by the dune, $12 \%$ of the mangroves were toppled and $26 \%$ appeared to have died, as of our January sampling. The November survey was similar with respect to toppling, with $14 \%$ of the trees fallen, but mortality was $43 \%$, exhibiting a $26 \%$ increase (significant at alpha $=0.025$ ) since January. Results from the resurvey in November were expected to show that some of the trees that appeared dead in January would have resprouted, reducing the overall mortality rate from the storm. However, these results indicate that mangrove mortality following the storm continued to increase, and suggest that some of the trees we saw resprouting in January could not recover and died sometime before November.

The recovery process at Shoy's Beach appeared to be slower than that of Halfpenny Bay Beach, and more complex. The elevation profiles of the transects showed little or no replenishment of the beach sand (Figure 2). Some of the sand that had returned to the beach by January, 1990, eroded away from the foreshore and backshore by November, even to the point of removing pioneer vegetation that was mapped in January, and killing other vegetation that had subsequently colonized the beach. This post-Hugo erosion appeared to be greater where the beach had detached from the beach rock (Transect $C$ ). In these areas, a pool of water was always present between the rock terrace and the beach to landward.

Vegetation recovery continued, albeit more slowly than that of the south barrier beach (Figure 3). Neither understory nor overstory cover showed a significant increase in November when compared to January (see Table 4). In the dune, where large overwash fans were colonized by grasses, vines and seedlings, understory cover increased, but not significantly (Figure 3 ). Although the severely-damaged trees on the dune continued to releaf through November, overstory cover was very variable, resulting in no significant increases. No changes in understory or overstory were found for the mangrove swamp community. Although the young plants initiated following the storm were growing vigorously, some of the damaged shrubs that had releafed by January appeared to have died subsequently, increasing the overall mortality from the storm. 


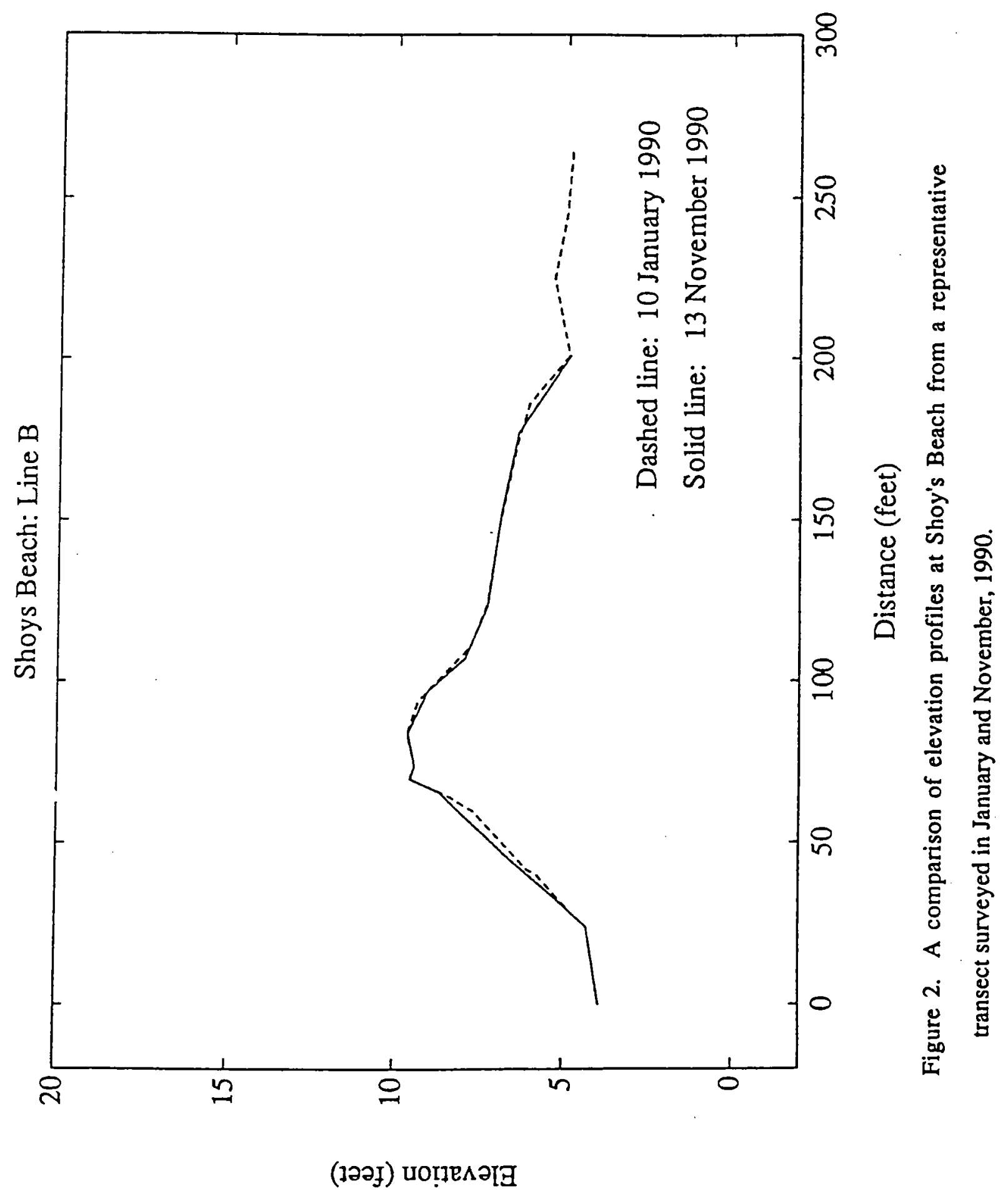



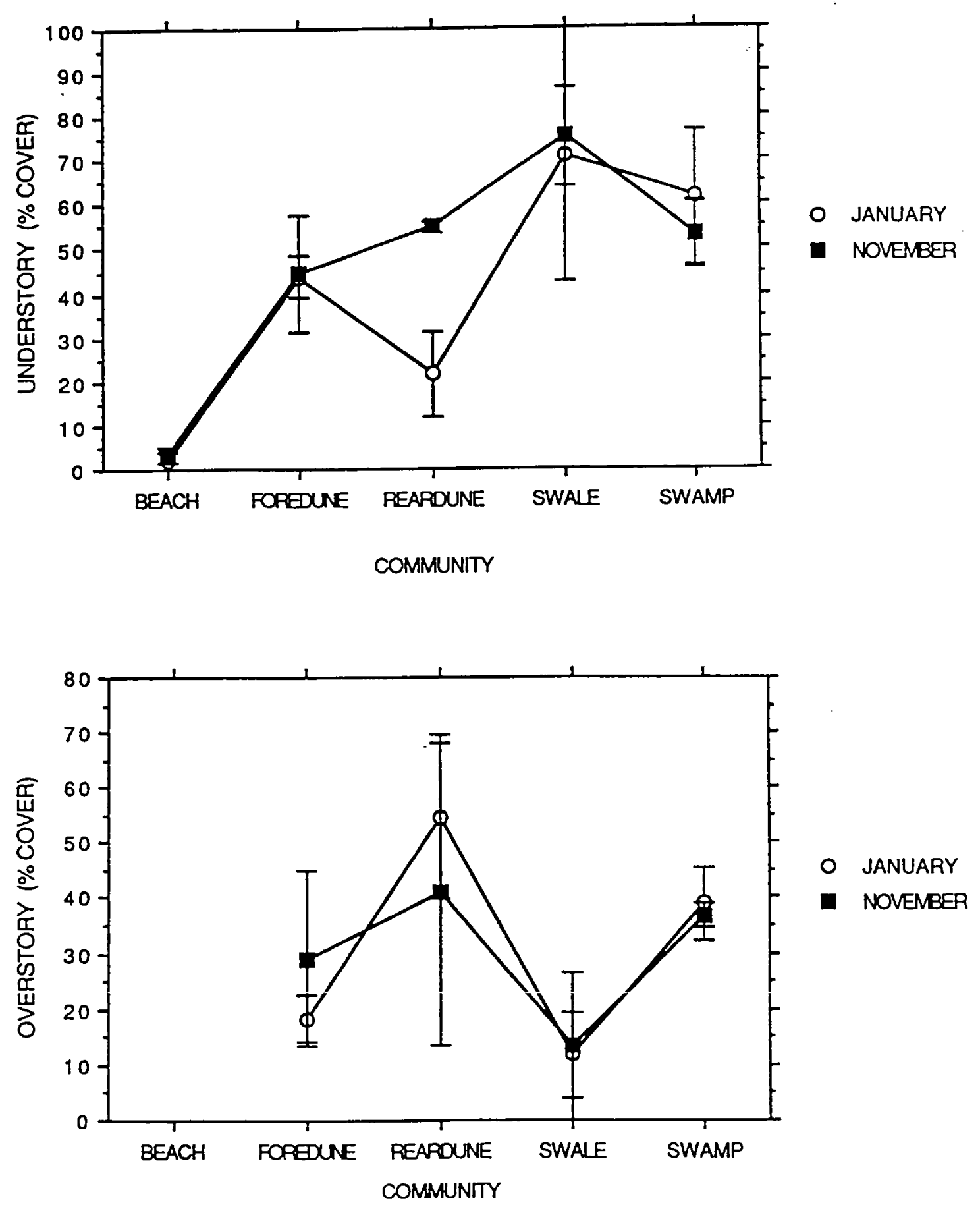

Figure 3. Plant cover means and their standard errors of three transects at Shoy's Beach. a. Understory cover. b. Overstory cover. Only communities exhibited significant differences $(\mathrm{P}$ value $<0.10)$. 
Table 4. Analyses of Variance of understory and overstory cover from three transects at Shoy's Beach surveyed in January and again in November, 1990 (3 and 13 months following Hurricane Hugo). In both analyses,percentage of cover varied significantly only with respect to community (i.e., no increase in cover was found from January to November.

\begin{tabular}{llcccc}
\hline $\begin{array}{l}\text { SOURCE } \\
\quad \text { Understory }\end{array}$ & df & SS (type III) & MS & F & P value \\
DATE & 1 & 288 & 288 & .63 & .4371 \\
COMMUNTTY & 4 & 16675 & 4169 & 9.09 & .0002 \\
DATE*COMMUNITY & 4 & 1507 & 377 & .82 & .5265 \\
RESIDUAL & 20 & 9169 & 458 & & \\
TOTAL & 29 & 27639 & & & \\
$\quad$ Overstory & & & & & \\
DATE & 1 & 5 & 5 & .01 & .9234 \\
COMMUNTTY & 3 & 4292 & 1431 & 2.52 & .0946 \\
DATE*COMMUNITY & 3 & 464 & 155 & .27 & .8443 \\
RESIDUAL & 16 & 9077 & 567 & & \\
TOTAL & 23 & 13839 & & & \\
& & & & & \\
\hline
\end{tabular}

\subsection{South Shore: Halfpenny Bay}

The dune line retreated approximately 32 feet during the hurricane (Table 3, Figure 4). Overwash deposits extended landward over 100 feet (into the swamp), and these deposits added up to two feet of new sand to the dune surface.

Significant beach deposits had formed at Halfpenny Bay Beach since the storm. These are indicated on Figure 4 by the wide berm seaward of the pioneer zone. Further accretion since January is illustrated in Figure 5 which compares a representative transect of the January and November profiles of Halfpenny Bay Beach. By November, sand accreted between the high tide and storm wrack lines which served to fill in the runnel that was prominent in January, 1990.

Plant communities were similar to those of Shoy's Beach, with the following exceptions: (1) no swale community existed, and (2) the foredune, dominated by trees, shrubs and grasses at the north site, was badly eroded by the storm at Halfpenny Bay, so that this community became part of the beach and received great storm damage (Figure 4). All of the grasses and shrubs were 


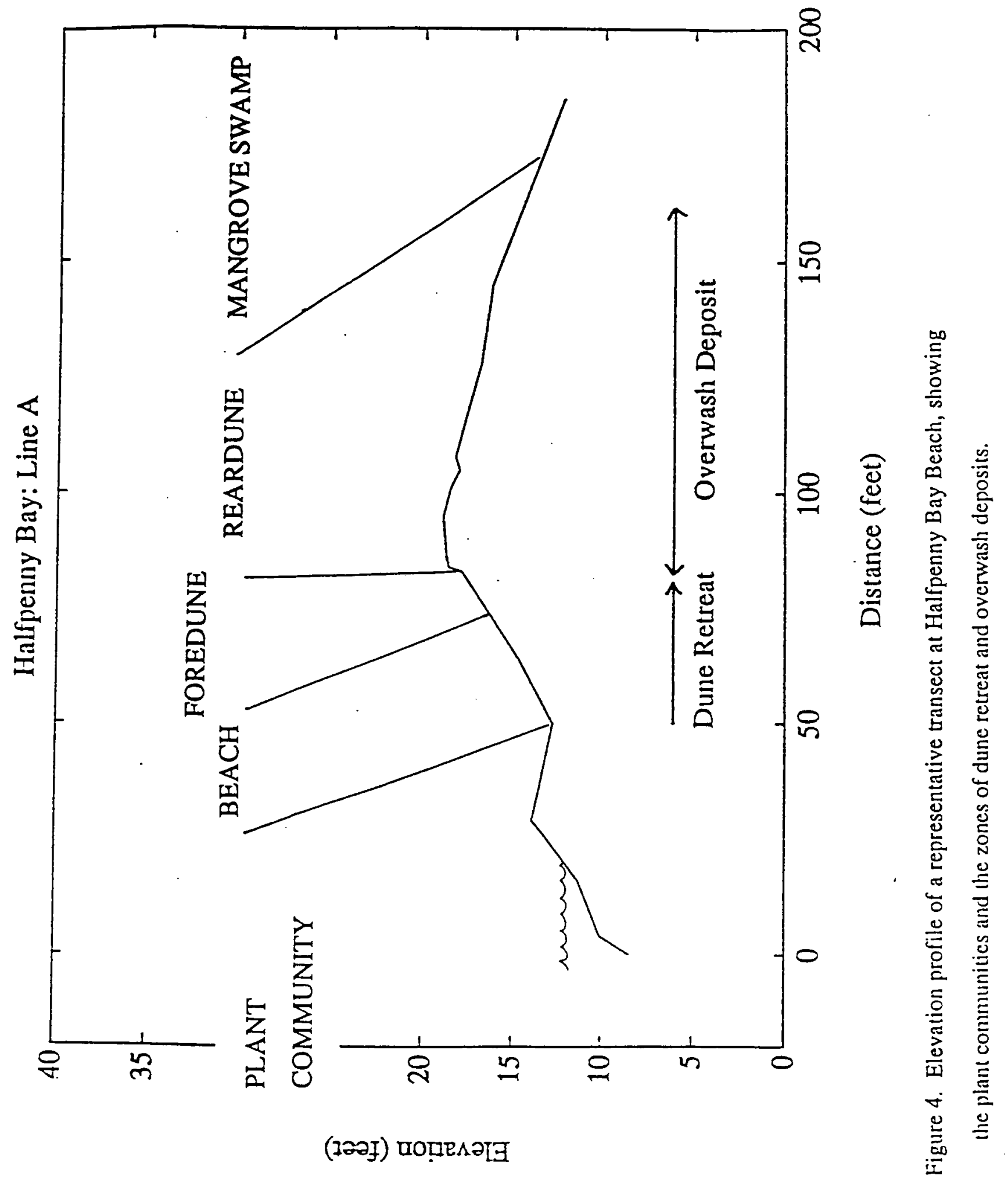




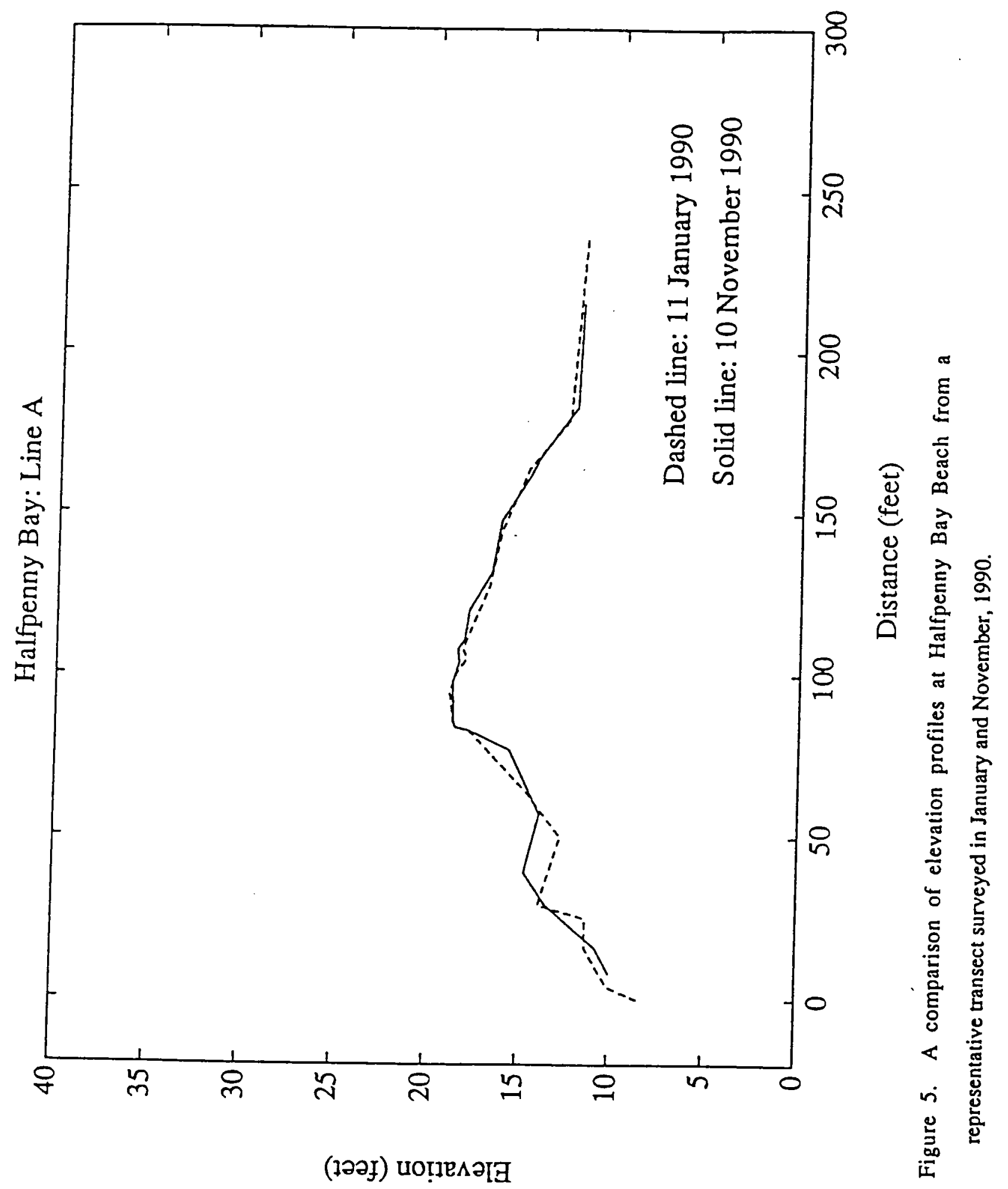


removed, and most of the trees toppled (80\%), though half of these had produced new leaves and were living in January and November (Sea Grape trees fared best). Thus this area had become part of the backshore, but it is clear that erosion was reduced by the presence of vegetation. However, this community will still be termed foredune because it is possible that the dune scarp will build seaward in the recovery period and the tree line will become the edge of the dune.

As on the north site, mangroves were heavily damaged, with $35 \%$ of the trees toppled and $22 \%$ mortality (many fallen trees remained alive). The November survey recorded $32 \%$ of the trees fallen and slightly greater mortality $(30 \%)$.

Vegetation has continued to recover at Halfpenny Bay, with more leaves on the damaged trees and seedling growth continuing. In general, the amount of vegetative cover on a per meter squared basis increased, but this increase was not significant for all communities (see Table 5). While ground cover of grasses, vines and seedlings increased only slightly on the foreshore of the beach and in the swamp, larger increases were found in the foredune and the reardune (Figure 6). The overstory of shrubs and trees increased significantly (Table 5), with rapid recovery occurring in the swamp, even though mortality rates from the storm were slightly higher by November. 


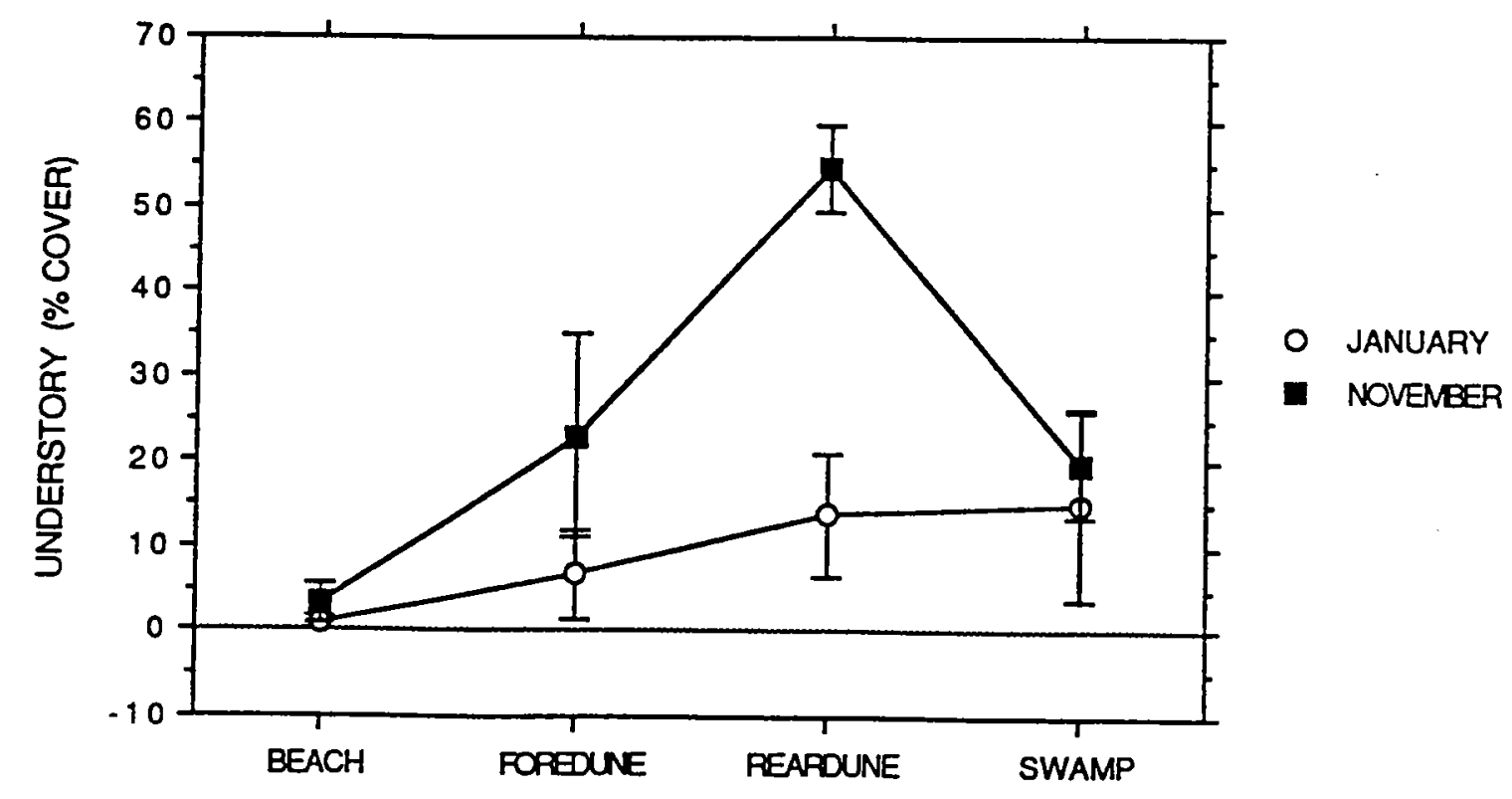

COMMUNTTY

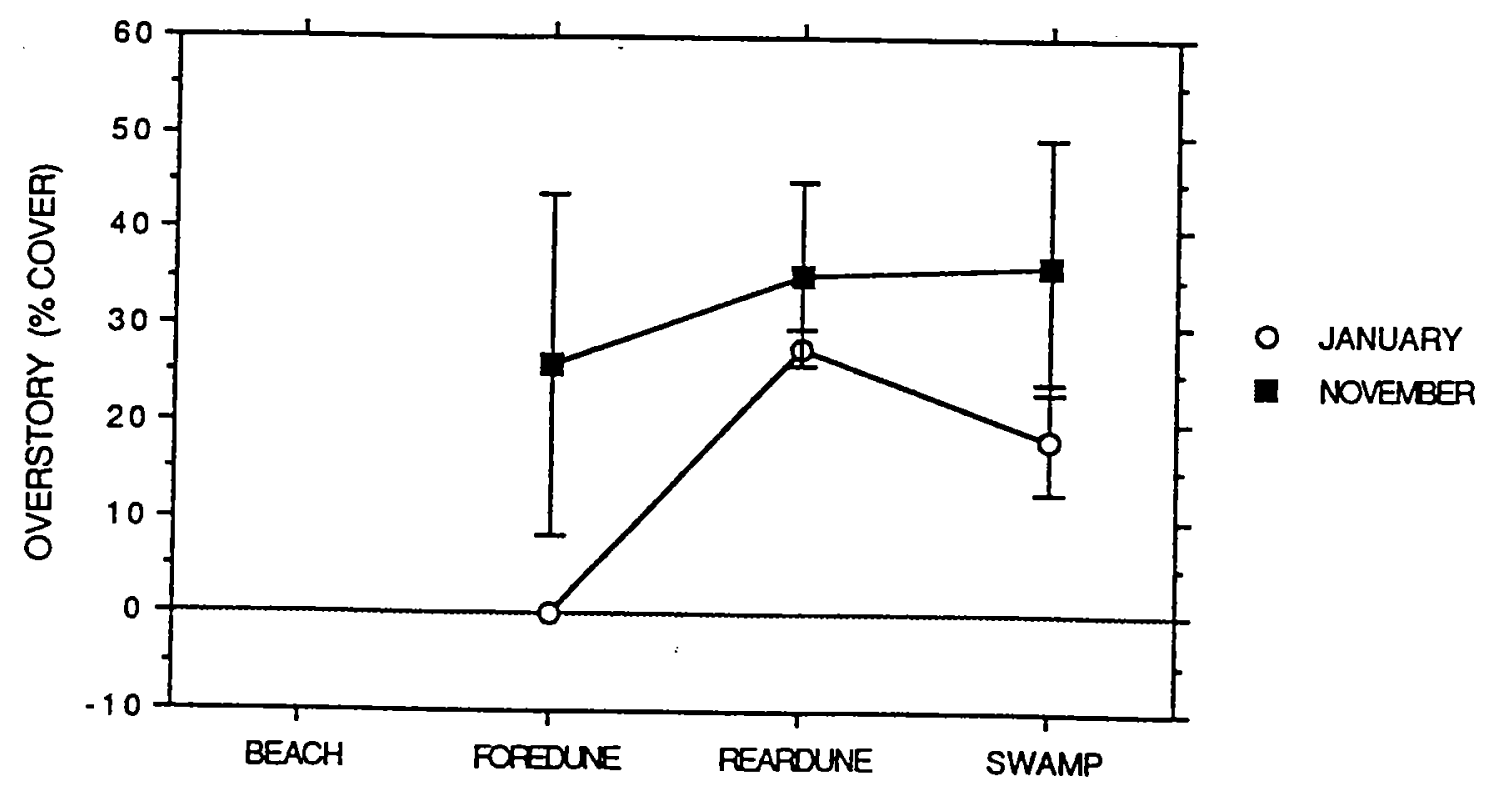

COMMUNITY

Figure 6. Plant cover means and their standard errors of three transects at Halfpenny Bay Beach. a. Understory cover. b. Overstory cover. The ANOVA (Table 5) indicates that plant recovery has increased both under and overstory cover in general. 
Table 5. Analyses of Variance of understory and overstory cover from three transects at Halfpenny. Bay Beach surveyed in January and again in November, 1990 (3 and 13 months following Hurricane Hugo). Understory cover varied significantly with respect to date, community and their interaction. That is, cover was found to generally increase from January to November, but this change varied among communities). In contrast, overstory cover was found to vary only by date (an overall increase in cover).

\begin{tabular}{llcccc}
\hline $\begin{array}{l}\text { SOURCE } \\
\quad \text { Understory }\end{array}$ & df & SS (type II) & MS & F & P value \\
DATE & 1 & 1567 & 1567 & 9.88 & .0063 \\
COMMUNTTY & 3 & 3158 & 1053 & 6.64 & .0040 \\
DATE*COMMUNITY & 3 & 1403 & 468 & 2.95 & .0643 \\
RESIDUA & 16 & 2536 & 159 & & \\
TOTAL & 24 & 8663 & & & \\
$\quad$ Overstory & & & & & \\
DATE & 1 & 1324 & 1324 & 4.25 & .0617 \\
COMMUNITY & 2 & 1147 & 574 & 1.84 & .2009 \\
DATE*COMMUNITY & 2 & 248 & 124 & 0.40 & .6804 \\
RESIDUAL & 12 & 3742 & 312 & & \\
TOTAL & 17 & 6461 & & &
\end{tabular}

\subsection{Site Comparisons and General Observations:}

Significant beach replenishment occurred at Halfpenny Bay in the first months following the storm, and further deposits had accreted by November. Such large post-storm deposits were not evident at Shoy's Beach, nor did sand accumulate on the beach after one year. In general, our island-wide survey suggested rapid post-storm sedimentation and beach replenishment at the south and southwest shores, and slower rates of recovery, if any, on the northern and northwestern shores.

In January, vegetative cover was about three times as great on the north site than on the south site (Figure 7; $\mathrm{P}$ value $=0.0003$ ). By November, this difference was eliminated ( $\mathrm{P}$ value $=0.127$ ) due to the greater recovery rates of the vegetation at Halfpenny Bay. Although the vegetation sustained greater damage on the south site, it is recovering more quickly than on the 


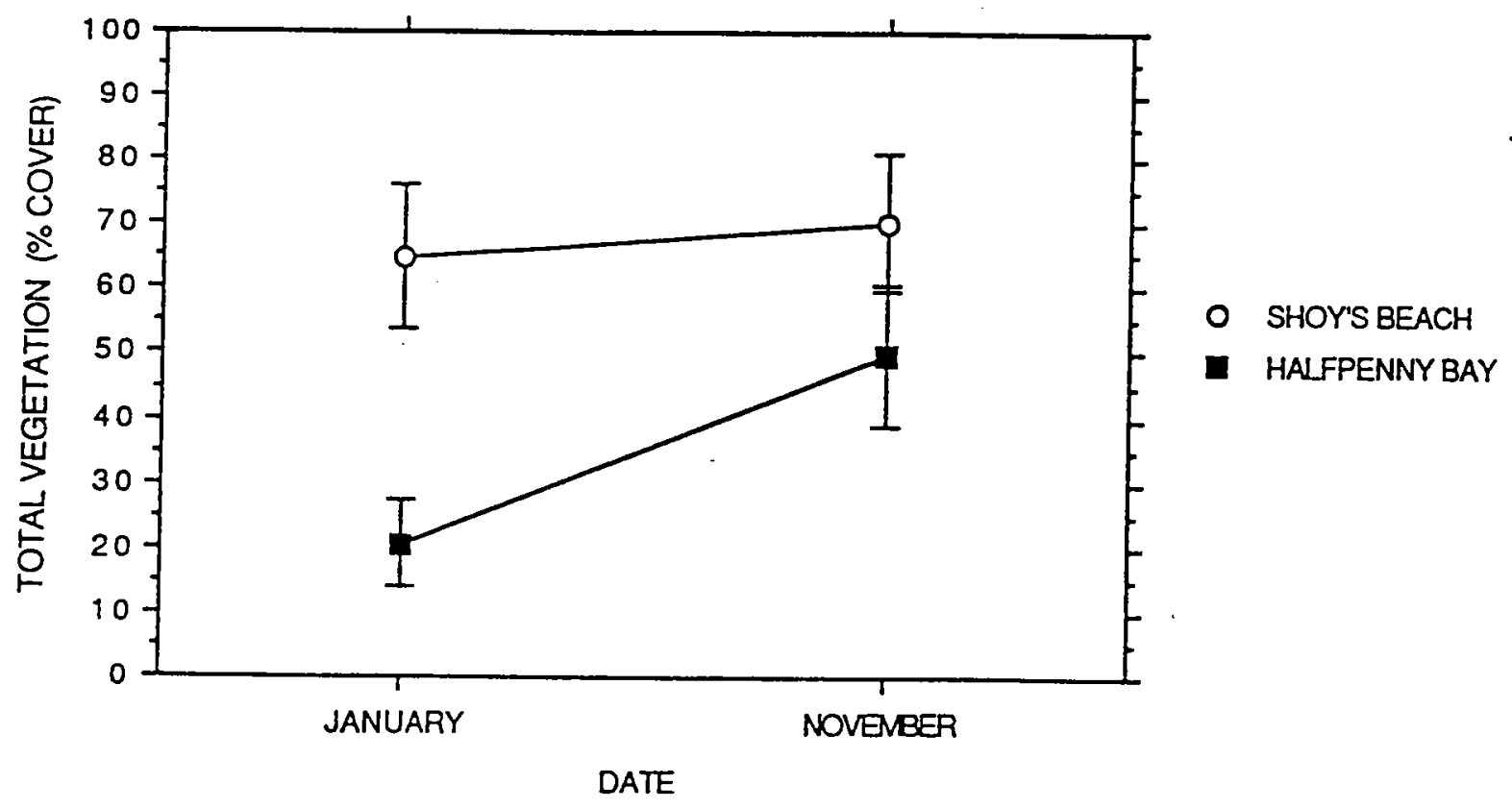

Figure 7. Plant cover means and their standard errors for the two survey dates (January and November, 1990) and sites (Shoy's Beach and Halfpenny Bay Beach). Date, site, and their interaction were significant at the 0.10 level. In January, Shoy's Beach exhibited more cover than Halfpenny Bay beach, but this difference disappeared by November as cover increased significantly at Halfpenny Bay, but not at Shoy's Beach. 
north site. Since quantitative measures were only made at one site on each coast, this observation cannot be applied to the south and north coast barriers and their vegetation, in general. However, our qualitative observations at numerous sites around the island suggest this may indeed be the case.

Vegetative recovery is far from complete, and overstory cover will probably increase approximately $20 \%$ in the dune and swamp habitats over the next few years, barring another great storm. Removal of much of the tree canopy and damage to shrubs by overwash fans has allowed more light to reach the understory. Colonization of the beach and foredune by grasses and vines was rapid and fairly complete by January. In the swamp, increased light has favored the succulent ground cover. Tree seedlings are numerous on the dune (Manchineel) and in the swamp (White and Black Mangroves). With time, it is likely many of these initiates will be recruited into the overstory community.

Apparently, trees and shrubs lost all leaves, and if they were not knocked down by the storm, lost many large limbs. Many trees were killed and toppled, but some of those toppled remained alive. There appeared to be lower mortality in the Sea Grape. At the dune scarp and on the dune, roots became rolled together, reducing further erosion and collecting sand as sedimentladen waves overwashed the dunes during the hurricane. By January, some of the Seaside Maho which appeared to have put out new leaves soon following the storm, had subsequently died. Similarly, White and Black Mangroves that had begun to releaf by January did not recover and had died by November. Most of the Red Mangroves lining the lagoons of Salt River Estuary and Altoona Lagoon appear to have been killed by the storm. It is not known why this species was so sensitive to this storm. Many of the White and Black Mangroves that survived and were releafing along their lower stems exhibited mortality of their upper stems. The cause of this is uncertain, but may include damage to the meristem tissue following defoliation (needed for putting out new leaves), mechanical damage to the vascular system by the storm, or physiological drought caused by high salinity water entering the swamp from the storm surge.

\subsection{Recommendations}

Most of the barrier beach systems studied on St. Croix were protected by offshore reefs. Yet their mere presence (these bodies are lenses of unconsolidated sediment), shows the strength of the forces that shaped them. Hurricane Hugo pushed these features landward, and future storms will do the same. Where human structures such as houses or parking lots occurred near the high tide line on beaches, they were usually damaged by the storm. Coastal structures or practices to defend ill-conceived structures from coastal advance disrupt coastal processes that control the 
development of barrier systems and ensure the continued presence of natural beaches. Thus it is recommended that no permanent structure is built on the barrier beach systems of the U. S. Virgin Islands.

Furthermore, on beaches where the natural coastal plant communities were removed (sometimes replaced with non-native species and groomed), our research suggests some of the dune building properties of the plant community were lost. It is important to maintain natural plant communities that support coastal sedimentary processes in the face of sea level rise and future hurricanes.

The one-day survey of damage to St. Thomas yielded the general impression that natural coastal systems on this island were not as severely impacted by the storm as those on St. Croix. However, the extensive storm damage that was found here leads us to similar recommendations concerning restrictions on development of human structures and alteration of natural plant communities of natural coastal systems.

\subsection{Conclusions}

Shoreline retreat was more extensive on the south coast (approximately $30 \mathrm{feet}$ ) than on the north coast (approximately $20 \mathrm{feet}$ ). At both sites, overwash deposits raised dune surface elevations up to 1 to 2 feet, and extended the landward toe of the dune into the mangrove swamp. Since the storm, beaches have regained sediment (extensively on the south coast, almost none on the north coast) from nearshore sources.

High winds with sand and salt spray, storm surge, and high energy waves caused severe damage to coastal vegetation including extensive leaf loss. Red Mangroves appeared to have been overwhelmed by the storm, and their recovery will likely be very slow. Several tree species succumbed following releafing (dune: Seaside Maho, swamp: White and Black Mangroves). Even so, many plants survived, and recolonization by ground cover and overstory species is proceeding. Most surprising was the survival of Sea Grape trees and Coastal Dropseed grass in areas that had been dune environments but were eroded by the storm waves and now are part of the beach.

Beach and dune vegetation reduced damage to the barrier landforms. Specifically, vegetation reduced erosion, collected overwash deposits on dunes, and protected landward vegetation. Our island-wide survey indicated that the areas where coastal development was impacted most severely by the storm were not protected by naturally vegetated coastal landforms (Cathy's Fancy, Halfpenny Bay, Grassy Point). Following the storm, remnants of the plant 
community served to collect sediment, and would have directly protected the coast from erosion if another storm had hit the coast. Thus, the removal of natural vegetation, even dead vegetation (i.e. grooming), is not recommended, since it will serve to trap sand on the dune during both recovery and future erosive periods. 
3.30 Interim Progress Report on 1989 Rapid Response - Hurricane Hugo Project:

"Impact of Hurricane Hugo on Endangered Species of Marine and Endemic

Forest Birds in the Lesser Antilles" (J. C. Haney)

\subsection{Introduction}

The West Indies have the highest areal rates of avian biodiversity in North America, and several islands that have single-island endemic species were impacted by Hurricane Hugo last fall. Determining region-wide, post-hurricane effects to birds and their habitats was one component of Woods Hole Oceanographic Institution's preliminary damage assessment program conducted during late 1989 and early 1990. Islands that have endemic species and that were partially or entirely within the track of Hurricane Hugo included Puerto Rico, Montserrat, Guadeloupe, and Dominica. Coupling between such coastal processes as hurricanes and interior forest and montane ecosystems is a unique attribute of small islands, and should be considered in the future conservation strategies for the West Indies.

\subsection{Principal findings and concerns}

Puerto Rico, Montserrat, Guadeloupe, and Dominica each have one or more endangered or locally-distributed endemic bird species. Populations of the endangered (i.e., federally-listed) Puerto Rican Parrot (Amazona vittata) and Yellow-shouldered Blackbird (Agelaius xanthomus) were dispersed and possibly reduced on Puerto Rico after the hurricane; the majority of montane forest habitat for Montserrat's national bird, the endemic oriole (Icterus oberi), was destroyed or very heavily-damaged by the hurricane; extensive damage occurred to forest habitat of the Guadeloupe Woodpecker (Melanerpes herminieri) on the eastern island of Basse Terre, and fewer woodpeckers were located during January 1990 than during a similar survey over the same route in May 1989. There was no significant hurricane-related damage to either the habitats or populations of the two parrots (Amazona arausiaca and Amazona imperialis) on Dominica.

\subsection{Implications and recommendations for future research}

Extensive and through followup studies of Hurricane Hugo are being conducted by many federal and commonwealth biologists in Puerto Rico at the species, community, and ecosystem levels. Long-term monitoring at the Luquillo National Forest will enable direct comparisons of pre- and post- hurricane conditions. Guadeloupe may be the only island that is not represented in post-hurricane recovery studies of wildlife. There is a need to compile and then convey results from studies in Puerto Rico and the Virgin Islands for use by wildlife and forestry department studying hurricane impacts or establishing monitoring programs on the smaller islands. 
3.34 Some initial effects of Hurricane Hugo on endangered and endemic species of West Indian birds

We noted the following general forms of initial damage to forest habitats on all four islands: 1) uprooting of trees in windfalls ("throw"), usually localized and confined to narrow swaths and exposed hillsides, 2) trees shorn of crowns and major limbs by high winds but remaining upright, and 3) defoliation of all leaves, flowers, and fruits. Less catastrophic forms of hurricane-induced damage ( 2 and 3 above) may result in suspension of fruiting and flowering for three or more years in highland forests. However, due to increased sunlight now reaching understories, delayed flowering and fruiting occurred at higher than normal levels in Puerto Rican mid-level and lowland forests six to eight months after Hugo's passage.

On Puerto Rico, Hurricane Hugo affected the populations or habitat of three endangered birds. Of 47 Puerto Rican Parrots (Amazona vitata) known to exist in the wild prior to hurricane passage, only 20 to 22 parrots could be located during a census conducted by the U.S. Fish and Wildlife Service, U.S. Forest Service, and Puerto Rican Department of Natural Resources on 22 December 1989. Whether this 50\% decline represents a real and obviously catastrophic loss, or merely dispersal into uncensused areas, is still unknown. Biologists knew of five wild breeding pairs prior to Hugo, but only three pairs have been currently located. At least one nest had eggs and a second nest had reproductive activity. By the beginning of this century, the localized, traditional nesting areas of the Puerto Rican Parrot had already enhanced susceptibility of the species to the ravages of hurricanes.

A small, remnant population of Yellow-shouldered Blackbirds (Agelaius xanthomus) formerly inhabited the Roosevelt Roads Naval Station and Ceiba region in eastern Puerto Rico. Only two individuals have been observed in this area since Hugo. The Roosevelt Roads population was already declining, probably from Shiny Cowbird (Molothrus bonariensis) parasitism, prior to the hurricane. Habitats of the large populations of Yellow-shouldered Blackbirds in western Puerto Rico and on Mona Island were unaffected by the storm. Assisted by defoliated trees, censusers counted 203 Puerto Rican Plain Pigeons (Columba inornata wetmorei) after Hurricane Hugo. Although this number is similar to 176 birds counted in January 1989, some of the pigeon's most important breeding habitat at Cidra was destroyed. An epizootic disease, possibly related to flooding from the hurricane, subsequently broke out and affected 90 of the 124 captive-reared pigeons. 
Hurricanes have acted as agents for other changes in the avian biogeography of the West Indies. The St. Kitts race of Puerto Rican Bullfinch was extirpated, and that the Puerto Rican Flycatcher declined on Puerto Rico following the hurricanes of 1928 and 1932. On the other hand, the Caribbean Elaenia on Montserrat was recorded as more common and widespread following habitat disturbances by hurricanes. Studies of bird populations following the passages of Hurricanes Gilbert on Jamaica and Hugo on Puerto Rico will continue. Preliminary results suggest that numbers of forest birds can actually exhibit local if only apparent increases when canopy-dwelling species move closer to the forest floor and upper-elevation species move to lowland areas in order to take advantage of denser, less-damaged vegetation.

Hurricanes are usually infrequent catastrophic events, typically confined to coastal or marine areas. However, terrestrial ecosystems are clearly not exempt from such coastal processes in much of the Caribbean. The destructive or disruptive influence of hurricanes on interior and montane forest habitats may be cause for special concern on smaller islands, especially the Lesser Antilles which harbor several endemic birds. Unlike continental areas and larger islands (e.g., Cuba and Hispaniola), small islands provide little protection and fewer refugia for bird populations during intense storms. Island forests may require more that 50 years to regenerate and regain the "climax" conditions existing prior to hurricane destruction. Hurricanes could be particularly devastating to populations of highly-localized species of West Indian birds already under cumulative pressure from other factors. Habitat preservation alone could prove to be insufficient response for preservation of avian biodiversity in the West Indies. Because chance events such as hurricanes are already known to directly influence dynamics of small populations of Caribbean birds, we believe hurricane effects should be considered during evaluation of future conservation strategies. 


\subsection{Relevant Virgin Islands General Coastal Program Elements}

- Policies to protect mangrove wetlands.

- Develop criteria on diking, filling and dredging activities.

- Identification of areas recommended as Natural Reserves for preservation and restoration.

- Refinement of regulations and criteria related to runoff and erosion control, shorefront community facilities, access dedication requirements and floodprone areas.

- Improved field and enforcement services.

- Development of hazards management plans.

- Development of Special Planning Area management plans.

- Clarification of public property rights in coastal resources.

- Regulation of coral and sand extraction activities.

- Updating oil spill contingency plans.

- Development of policies on erosion hazards, beach access and geologic hazards; inventorying coastal hazards and coral reefs; and the provision of field activities in important island areas. 


\subsection{Some Institutional Adjustments/Responses}

- Carrying out analyses of disaster threats and vulnerabilities.

- Making inventory of available resources.

- Enacting the necessary legislation, at territorial and local levels.

- Conducting training in disaster prevention and preparedness.

- Coordinating activities with scientific organizations.

- Insurance policies, subsidies and costs need to be assessed.

- More public education, including use of the community infrastructure.

- Organization, including lines of authority and placement of leadership function.

- Logistics, including movement of people and supplies.

- Communications, including use of an operations center.

- Integration with private sector and voluntary organizations.

- Regional relationships throughout the eastern Caribbean should be enhanced.

- Relevance, a consideration of the actual levels of risk for specific threats.

- Governments should clearly define or identify, in advance of crisis situation, the official source or group from which they will accept scientific information and advice.

- Information from event scientists/experts should include:

- Observational information--an up-to-date description of the event/activity.

- Present trend information. 
- Forecast information based on probability, with an indication of the scientists' confidence in the probability rating.

- The Virgin Islands government should determine and establish for their own use what levels of risk are acceptable to their islands and communities.

- One method of determining acceptable risk involves the study of case histories of previous events and the establishment of levels of risk in relation to probabilities of occurrence. This will provide at least a crude formula for decision-making during a crisis when the information provided by the scientists should include forecast information on the probability basis.

- In some emergencies, there may be a gradually increasing hazard (over a period of time), during which is is impossible to pinpoint the time when evacuation is imperative. The prior establishment of a policy on levels of acceptable risk, based on model situations, evacuation or for other preventive action with consequent social and economic benefits needs to be accomplished.

- In the short term, local seminars coupled with publicity in the local media, should be organized.

- In the long term, seminars should be held at frequent intervals until preparedness plans are completed by each individual island.

- In order to maintain public awareness, in the long term, plans should include a strong component for public education.

- The Virgin Islands government should promote the preparation, implementation and enforcement of building codes, including setback/zoning regulations.

- Essential to the forecast of sea level change for the protection of life and property is the establishment of a tide gauge network with continuous transmission of signals from a number of stations to a data recording and analysis center, likely NOAA operated. 


\subsection{An Example of Storm Defense Adjustment/Responses For Use by the}

Virgin Islands Government

- North Carolina has taken aggressive steps against full-scale development in hazardous areas of the coastal zone. First, the Coastal Resources Commission (CRC) has established tough erosion set-back regulations. Large structures must be set-back 60 times the average annual erosion rate, and small structures set-back 30 times the average annual erosion rate. In no case can development be closer then 60 feet to the shore's vegetation line.

Second, structural stabilizers are prohibited on any beaches. No seawalls or groins are allowed. This policy choice is based on belief that providing protection for public enjoyment is more important than protecting private property.

Third, the state legislature provides funding to North Carolina's CRC to purchase shore areas which can no longer be developed because of the strict set-back regulations. This land must , in turn, be keep for the public's use and enjoyment, similar to programs of the Nature Conservancy and Audubon. Many communities have received funding through the CRC to survey beach areas and establish regional beach access ways, assuring citizen access to local beaches.

The North Carolina Coastal Management Program (NCCMP) was approved in 1978. The major legislative authority of the NCCMP is the Coastal Area Management Act (CAMA, which designated the Department of Natural Resources and Community Development (DNRCD) as the agency responsible for coastal management in the state. Under CAMA, the DNRCD administers a coastal area permitting system covering all major development activities in the state's coastal zone, including the issuance of dredge and fill permits under state law. The CAMA also provide the DNRCD shall review all local ordinances and regulations for compliance with the guidelines and standards established under the Act. The CAMA established the Coastal Resources Commission (CRC), composed of 15 members appointed by the governor to represent certain coastal interests: commercial fishing, wildlife, recreational fishing, marine ecology, coastal agriculture, coastal forestry, coastal land development, marine-related business, engineering, state and national conservation organizations, financial institutions and local governments. The CRC is responsible for the development of policies and State guidelines for the designation and regulation of Areas of Environmental Concern (AECs) and the establishment of State 
guidelines for local land use planning in the coastal area. The CRC is also responsible for initiating action on new coastal resource management issues.

The basic goals of the NCCMP are:

1. To provide a management system capable of preserving and managing the natural ecological condition of the estuarine system, the barrier dune system and beaches to preserve and perpetuate their natural productivity and their biological, economic and esthetic values;

2. To ensure that the development or preservation of the land and water resources of the coastal area proceeds in a manner consistent with ecological considerations;

3. To ensure the orderly and balanced use and preservation of coastal resources on behalf of the people of the state and the nation; and

4. To establish policies, guidelines and standards for the protection, preservation and conservation of natural resources; the economic development of the coastal area; recreation, tourist facilities and parklands; transportation; the preservation and enhancement of historic cultural and scientific aspect of the coastal area; the protection of common law and statutory rights in the lands and waters of the coastal area.

The NCCMP uses a two-tier approach to manage the state's coastal resources. The AECs comprise the first tier and activities in these areas are regulated by CAMA permits. The designated AECs include coastal wetlands, estuarine waters, public trust areas, estuarine shorelines, ocean beaches, frontal dunes, ocean erosion areas, inlet lands, small surface water supply watersheds, public water supply well fields and certain fragile natural resource areas. The second tier includes all areas outside the SECs that lie within the 20 coastal counties. The lands are managed through other state laws and the CRC-approved local Land Use Plans (LUPs). The NCCM's objectives and management approach encompass four major activities: permitting activities, development of LUPs, financial and technical assistance to local governments and CRC policy formulation. 
6.0 Summary For The Virgin Islands--Institutional Responses and Socio-economic Modelling

Present situation

Three issues are at hand for purposes of this survey:

- Institutional responses to current situation;

- Future institutional responses to storm change;

- Current strategies for socio-economic modelling.

Institutional Responses to Present Situation

The most pressing issues of environmental policy associated with possible increasing storminess facing Caribbean nations currently is what to do now, if anything. For the moment, we are not clearly looking at storm changes but rather at the risk for future changes. The basic missing element is not a defense response but rather information. Several generic responses are available in the face of risk to avoid or reduce it:

- information gathering;

- risk pooling/diversification;

- flexibility:

(a) reduced fixed commitments

(b) procrastination (wait \& see)

(c) insurance

(d) safety (conservation)

More specifically, several mechanisms can be identified for risk spreading (and thus reduction):

- insurance

-moral hazard problem

-adverse selection problem

- share markets

- contracts \& futures markets

- mergers

- governmental sharing 
From an economic perspective, risk bearing is a costly factor of production. As more risk arises, it is helpful to shift it onto the most efficient risk bearers:

- entrepreneurs

- insurance

- international firms and organizations

- governments and government associations

Factors that enter the planning and projection process in addressing heightened natural risks includes:

- ex ante/ex post

- defend/retreat

- centralized/decentralized

- technology change/retrofit

- planned/ad hoc

- rational/expectations/mistakes

- uncertainty

Future Institutional Responses

There are several good reasons for skepticism about the need for current responses:

- uncertainty of effect

- incremental change

- tradeoffs

- rational behavior

- economic discounting

- technological change

An important reason is the expectation of timely future responses as knowledge grows. People and nations can be expected to adjust. Give any current estimate of "passive" damages, future adjustments can be expected to reduce expected damages. Adjustments will include:

- Defensive measures

- Factor recombinations 
- Technological change

Socio-economic Modelling Strategies

- Transgression Scenarios

- "Dose-Response" Functions

- Economic Projections

- Accounting for Adjustments

- Discounting Issues

- Holistic Systems

(expensive, unrealistic, infeasible)

- Strategic Choice and Models of Decision Making

- "Policy \& Management Analogues"

Physical Modelling Strategies

- Hypsometric Curves

- Geomorphic based transgression elevations

In view of the extensive scope and the paucity of even first order approximations, we urge the development of an island-wide appraisal based on very coarse and inexpensive modelling technique developed at WHOI requiring only readily-available national accounting data and scientifically credible hypsometric transgression scenarios (RSLR, changes to tidal prism, land loss). 


\subsection{Processes and Management in the Coastal Zone: An Overview}

Todays coastal zone is one of the regions of densest human population, where peoples have gathered to take advantage of commerce, fisheries harvests, moderated weather, and the chance to contemplate and explore the world living beyond the horizon. As the total coastal population increases, and as the demographic shift to these areas continues, the coastal zone will become increasingly encumbered by the trappings of modern society: increased recreational demands, waste disposal issues, over-utilization of marine fisheries, encroachment on valuable and often irreplaceable coastal resources, and other associated problems. How humankind will cope with these additional demands in the future is not clear. The continued attraction of the coastal zone depends in large part on how man responds to these accelerating demands; human stresses may continue to change the very structure that drew him there in the first place.

The stresses on the coastal zone take many forms and result from physical and chemical disturbance. Partly stresses arise from encroachment on marine resource areas: coastal vegetative communities and coral reefs, for instance. This disturbance not only removes the direct contribution of that ecosystem, but also translates through the food chain to other resource areas, such as wildlife.

Other stresses arise as a result of navigation and shipping requirements. The tendency towards more economical use of larger and larger vessels (especially cruise ships and tankers in the USVI) has been accompanied by increased demands for deeper and wider channels. Such navigation requirements have altered habitat, particularly within shallow estuaries and lagoons. The habitat alteration arises not only from direct destruction during dredging, but also indirectly as deeper channels have altered circulation patterns and intrusion of saltwater deep into bays and

rivers. Such intrusion has altered the chemical balance of the ecosystem which in turn has dramatic effects on biological resources.

Similar habitat alterations have arisen as a result of groundwater and surface water mismanagement. Freshwater inflow to the coast has been altered, in terms of timing of such discharge, magnitude of freshwater discharge (dams and irrigation projects altering the hydrologic cycles), and position of such outflow (through stabilization or re-routing of ghuts). These changes result in altered shelf circulation patterns in some instances, and to altered delivery of water, nutrients and sediments to the coastal oceans. Such alterations in delivery have affected the marine food web severely in some cases, by changing the substrate, by altering food species distribution, or by changes in the salinity balance with its associated physical or biological processes. The stability of the coastline itself has been threatened, partly by alteration of sediment delivery to the coast. On a small scale, coastal erosion control and "property" protection measures have had significant local effects. 
The introduction from various sources of pollutants to the marine environment has also resulted in significant stress to coastal resources. Massive oil spills, including the WAPA spill, focus our attention on the delivery to the marine environment of chemicals necessary to modern society. However, many other sources of pollution are more significant than oil spills, but are not as well publicized because their effects are not as dramatic, and their time scale is longer. During the long term, chronic leakage of small amounts of toxic or nutrient chemical can cause even more dramatic changes to a coastal ecosystem than the acute trauma caused by an accidental spill.

Other stresses on coastal resources exist along the coastal oceans, including overfishing and recreational use. Both of these sources of stress can result in degradation of habitats, and even changes in ecosystem structure and function. Overfishing can remove food sources or predators from the food web, changing the relative proportions of organisms. Recreational use can make certain resource areas unavailable at certain times of the year, with impacts on the ecosystem. For instance, increased beach usage might make nesting by birds or turtles impossible, or it might reduce the probability of successful hatching. Such dangers have been felt along many coasts of the world, resulting in endangerment of certain species.

The coastal zone is a unique area, as it represents the interface between the land, the open ocean, and the atmosphere. Exchange processes across, and interactions between, these interfaces tend to be stronger in the coastal zone. Besides active physical processes, the biogeochemical interactions also are strong, and much of the cycling of contaminants takes place in this zone before delivery in final form to the deep ocean. In order to manage this delicate resource area most productively and efficiently, we must understand the processes occurring with it. Here we focus primarily on the physical processes, with some reference to the interaction of the physical processes with the biological and chemical processes of ultimate interest in these zones.

\subsection{Physical processes in the coastal zone}

Physical processes within the coastal zone take on many different forms, often changing seasonally with weather or with delivery of sediment and water to the coast. These physical processes help determine the ability of organisms to colonize in specific areas, and also help in dispersal of planktonic stages of various types of organisms. Thus, the physical environment shapes the ecosystem structure; some pertinent aspects of the effects of physical forcing are discussed below. The emphasis presented here is on a brief description of the physical process, and then those important areas requiring further research in the future for more complete understanding.

Because we cannot directly measure all relevant parameters in sufficient detail, a major trend in the field of physical processes is the simulation of ocean processes through mathematical 
models. For these simulations to be of use, good data sets are needed to evaluate the numerical model output. Some specific modelling approaches and needs are described here.

\subsection{Surface Gravity Waves:}

A major contributor to physical mixing processes are surface gravity waves, or wind waves. These are the waves generated by the transfer of momentum from the wind to the ocean surface. They are responsible for motions within the water column, as well as vigorous mixing at the sea bed.

\subsection{Quasi-steady currents (winds, tides and wave-induced):}

A second type of physical forcing having great impact on coastal ecosystems and biogeochemical cycling is associated with quasi-steady currents: those that are much longer in period than surface gravity waves. These currents are generated by a variety of different physical processes.

During storms, winds can pile water up against the shore, creating higher water levels known as storm surge. Wide continental shelves tend to have larger storms surges; for instance the U.S. east coast's broad shelf adds storm surges of up to $3 \mathrm{~m}$ above normal. By contrast, narrow shelves (e.g. St. Croix) have much smaller storm surges, on the order of $0.2 \mathrm{~m}$ or less. The interaction of higher water levels due to storm surge, stronger quasi-steady currents, and larger wind waves from the storm passage, leads to destructive erosion along coasts, and to severe changes in the water column and at the bed of the ocean, thus altering sediment transport and physical effects on the ecosystem.

Another type of quasi-steady current is generated by astronomical tides. These tides generally have dominant periods which are either semi-diurnal (twice a day) or diurnal (once a day). The period of the dominant tide is partly a characteristic of latitude of the site, and partly dependent on the shape of the basin within which the tide acts. Tidal ranges vary geographically, ranging from areas have almost no vertical tides, to coastal areas experiencing vertical tides of $10 \mathrm{~m}$ or more, with consequent strong tidal currents. Additionally, the normally oscillating tides can generate steady, or more properly residual, currents, which add a net bias to the direction of local transport. Such residual currents, generated by the nonlinear physics associated with wave-wave interaction and interaction of the wave with the local bathymetry, may strongly affect the dispersal of planktonic forms of larvae and other organisms, and on the net transport of pollutants into and out of an area.

A third type of current is due to surface gravity wave motion. Just as oscillating tides can generate steady currents through interaction with the bottom or interactions between waves, so can surface waves be rectified in shallow water to produce quasi-steady currents. These currents might 
be within the surf zone (e.g. longshore currents), or may be offshore and superimposed on underlying topography. For instance, residual wave-induced currents might be generated over sand ridges in shallow water, or over tidal deltas near tidal inlets.

\subsection{Sedimentation processes}

Understanding of the mechanics of sediment transport is required if we are to forecast the evolution of shorelines. At present, processes of erosion and accretion along our coasts are understood qualitatively. We know how natural and anthropogenic processes affect the erosion and building of our coasts. We know something of the physical processes that govern the response of the coast to various activities. However, we have no capability to provide guidance about the fate of sediments, and about the evolution of coasts, from a quantitative standpoint. Although shoreline structures, for instance, might threaten the stability of a section of coast, we cannot at present predict how fast that instability might occur,or how far it might extend.

\subsection{Interaction of physical forcing and morphology of coasts}

Waves and currents approaching the shore mold the coast according to the severity of the physical forcing, as well as the erodibility of the coast. For rocky shorelines that are not easily eroded, sandy beaches are rare and the coast may consist of steep seacliffs, fronted perhaps by a narrow cobble or sand beach. A coast that is sinking relative to sea level (a submergent coast) may have many such rocky shorelines, as the physical processes are not allowed to work long enough to break down the seacliffs to derive enough sediment to form a beach.

Along coasts consisting of more erodible sedimentary deposits, or along coasts that are emergent (rising relative to sea level), the coasts commonly tend to have sandy beaches and related resources. Areas that are submergent, but that have abundant sediment supply, commonly form extensive lagoons or estuaries, (resulting in the development of mangrove wetlands for instance). Areas that are emergent and that have good sediment sources tend to build wider beaches, commonly having multiple beach ridges or other indications of ample sediment supply and stable beaches.

Man's activities can also have a significant effect on coastal morphology and stability. The type of coast that exists in an area may control in large part the acceptable management practices. Management schemes applicable to one type of coast may be inappropriate for other types of coast. These differences and distinctions must be recognized when legislative, regulatory, or policy decisions are formulated for coastal environments.

Mangrove wetlands are regions of particular concern, since their existence relies on a balance between sediment supply, freshwater/saltwater balance, water level, and water quality. 
Alteration of any of these parameters may cause significant shifts in the vegetation patterns, and hence on the character and perhaps stability (or mobility) of the coast.

\subsection{Physical stresses on coasts: natural and anthropogenic}

Physical stresses are placed on the coast by nature and by humankind's activities. Natural stresses include rise of sea level along many coasts, continual pounding of the coasts by waves and tides, interruptions in sediment supply by droughts and river jumps and similar events. Anthropogenic influence is similarly broad in scope, and has been increasing in recent years. The human influences on coastal stability are many and varied, and a partial listing includes: land reclamation resulting in loss of coastal habitat; submergence of land due to withdrawal of groundwater; dredging and the construction of navigation structures along the coast to enhance navigation, resulting in interruption in amount and regularity of sediment supply; construction of shore protection structures along the coast, saving the upland but reducing the supply of sediment to maintain an equilibrium coast; mining of sands from beaches and offshore; and interruption of natural river flow to enhance irrigation.

These physical stresses cause imbalances in the delicate equilibrium that has marked many coastlines for hundreds or thousands of years. As sea level rises globally, many coasts that are not tectonically emergent are retreating constantly. The ability of shores to retreat is essential to maintaining a stable landform. Retreating coasts, however, are anathema to shorefront development, leading to an inevitable conflict between those who would protect investments and those who would retreat in the face of overwhelming natural forces. Protection of investment will prevail until the total costs of this subsidy are summed. The result is a reduced stability of the coast, a state of siege along many coasts whereby the infrastructure is constantly threatened by storms and other natural disasters. Only by recognizing this imbalance and man's contributions to it will the coast be able to regain its natural defences and immunities to the forces that constantly shape it. This is the challenge for effective coastal management in the future.

\subsection{Management}

The need for effective and foresightful management is underscored by the recent concern over man's impact on global climate. The release of trace gases into the atmosphere has changed the composition of the climate, and threatens the thermal balance of the globe. If the thermal balance is indeed altered as some scientists have predicted, the rate of coastal change likely will increase. For instance, sea level may rise at an accelerated rate if the atmosphere warms, largely due to contributions of meltwater from land glaciers and thermal expansion of the heated ocean surface. Such rise in sea level would have nearly global consequences, threatening in a shorter time period even more sections of the coastline than presently are threatened. Climate change 
impacts on the coastal zone include the potential for more rapid inundation of coastal property and accelerated loss of coastal resources; destruction of coastal property caused by increased frequency, intensity, and altered paths for extratropical and tropical storms; changes in water circulation arising from differing water levels, streamflows, and bottom configuration; changes in water quality arising from differing temperatures and biogeochemical cycling under increased temperatures, perhaps accelerating coastal toxic blooms such as red and brown tides; and so on.

\subsection{Biological and chemical interactions with physical processes}

Biological and chemical processes both respond to changes in physical processes, and in turn may alter those physical processes. The fate of wetlands is strongly tied to the ability of the coast to withstand erosion. As the coast erodes or accretes, the wetland resources may shift or disappear. On the other hand, their disappearance may decrease the ability of the coast to withstand such erosion, thereby accelerating the loss of the resource area. For many questions, the knowledge of physical processes themselves is not the ultimate goal. For coastal stability, beach erosion (a physical process) is the factor required by managers. However, for many coastal issues, physical processes only moderate and alter the biological and chemical systems that are the root of the coastal concern: human health, biological community structure, ecosystem health, and eutrophication, for instance. Physical processes may trigger, shellfish toxicity and toxic algal blooms: and may also contribute to their spread. The ultimate question concerns the effects of the algal blooms on biological processes and human health. Thus, when addressing the research needs for applied coastal problems, the questions may be of a biological or chemical flavor. Knowledge of physical processes and their interaction with the biology and chemistry cannot be separated.

\subsection{Management of coastal resources}

How do we preserve the coastal environment in a healthy state where it is now healthy, and how do we restore those areas that have been impacted adversely by man's activities? This challenge must be met while keeping in mind economic constraints as well as the desire for continued and even increased human habitation and resource utilization in the coastal zone. The multiple use conflicts that pressure coastal management are difficult to resolve globally, and almost always must be addressed on a local basis. Lacking a global or regional resolution, however, local management decisions may be ineffective and may result in a discontinuous framework. Since coastal oceans communicate effectively with each other through natural mixing and dispersion

processes, the results of discontinuous management may be a degraded marine resource along the entire shore, even when good management decisions have been made in some places. This connectivity between the coastal areas mandates a regional view for management at the very least, 
considering the effects of management practices at one location on resources some distance away.

Several primary management issues arise. First, prevention and control strategies must be implemented to reduce pollution inputs in the future. Eventually, there will be an increased need or desire to implement international controls on marine pollution. A second need is for clean-up and improvement of existing, deteriorating environments. In most cases, this clean-up may be more expensive than source control, and to be economically feasible, such clean-up must focus on those sources or contaminants most responsible for the ecosystem degradation. Only scientific investigation can provide this information. Finally, a carefully-considered monitoring program must be undertaken to monitor the pulse of the coastal resources. By economic necessity, such a monitoring program must be parsimonious. Only by careful scientific analysis will such a limited program produce unambiguous data relevant to monitoring the health of these systems. Much money is wasted world-wide on an incomplete or poorly considered monitoring system. To achieve the efficient and effective monitoring goal, new technologies must be developed to acquire the interdisciplinary measurements needed for this purpose.

Continued interaction between the policy and management community and the scientific community, expressing the needs and resources of each group is essential. For instance, much science is not able to be incorporated directly into management practice, but still must be completed in order ultimately to address fundamental management needs. The communication must be specific to allow policy makers to communicate their perceived needs and time requirements, and the scientist must consider these when making recommendations on the scientific results. Conversely, policy makers must acknowledge that improved understanding of some fundamental management problems will require years of continued investigation, with results that at least indirectly, if not directly, will bear on recommendations for improved management strategy. This type of communication, if successful, will help assure proper progress in science leading to real management needs.

\section{Acknowledgements}

We gratefully acknowledge the following organizations and individuals for providing the support needed to prepare this report. The Coastal Research Center of the Woods Hole Oceanographic Institution (via a grant from the Andrew W. Mellon Foundation); NOAA National Sea Grant College Program Office, Department of Commerce, under Grant No. NA86-AA-D-090, WHOI Sea Grant Project No. R/M-23-PD; and the U.S. Virgin Islands Department of Planning and Natural Resources. Thanks to Alan Smith and Onaje Jackson of the USVI-DPNR for research support, and we acknowledge modified contributions originally prepared by J. Archer (UMASS); J. Broadus (WHOI); R. Sheets, R. Case, M. Mayfield and L.A. Avila all of NOAA National 
Hurricane Center. We also wish to thank Pamela Barrows for helping to organize and edit the report. (This report has not been submitted to the refereed literature.) 
Agardy, M. T., 1989. Hurricane Hugo - Related Impacts on the Marine Ecosystems of the Lesser Antilles. Unpublished Trip Report, Woods Hole Oceanographic Institution, Woods Hole, Massachusetts, USA.

Anderson, O. M. and P.S. Lobel, 1987. The Continuing Enigma of Ciguatera. Biological Bulletin, 172 (1), 89-107.

Archer, J.H., 1988. Coastal Management in the United States: A Selective Review and Summary. The University of Rhode Island Coastal Resources Center International Coastal Resources Management Project, Technical Report Series TR-D-1, 24pp.

Avila, L.A., 1990. Atlantic Tropical Systems of 1989. Monthly Weather Review, 118 (5), 11781185 .

Baird, W. F., B. L. Edge, O. T. Magoon, and D. D. Treadwell, 1990. Cyril E. King Airport Runway Extension and Vicinity at St. Thomas, U.S. Virgin Islands Damage During Hurricane Hugo. Shore \& Beach, 58 (4), 64-71.

Boucher, D.H., 1990. Growing Back After Hurricanes. Bioscience, 40 (3), 163-166.

Boucher, D. H., J. H. Vandermeer, K. Yih, and N. Zamora, 1990. Contrasting Hurricane Damage in Tropical Rain Forest and Pine Forest. Ecology, 71 (5), 2022,2024.

Broccoli, A.J. and S. Manabe, 1990. Can Existing Climate Models Be Used to Study Anthropogenic Changes in Tropical Cyclone Climate? Geophysical Research Letters, 17 (11), 1917-1920.

Brooks, D. A., 1983. The Wake of Hurricane Allen in the Western Gulf of Mexico. Journal of Physical Oceanography, 13 (1), 117-129.

Brower, D.J. and T. Beatley, 1988. Natural Hazard Mitigation Plan For the U.S. Virgin Islands. Monograph Prepared For the Virgin Islands Territorial Emergency Management Agency (VITEMA), 39pp.

Burdick, D. M. and G. S. Giese, 1990. Effect of Hurricane Hugo on Coastal Landforms and Plant Communities in the U.S. Virgin Islands - Rapid Response Phase. Unpublished Trip Report, Woods Hole Oceanographic Institution, Woods Hole, Massachusetts, USA.

Case, B. and M. Mayfield, 1990. Atlantic Hurricane Season of 1989. Monthly Weather Review, 118 (5), 1165-1177.

Conner, W. H., J. W. Day, R. H. Baumann, and J. M. Randall, 1989. Influence of Hurricanes on Coastal Ecosystems along the Northern Gulf of Mexico. Wetlands Ecology and Management, 1 (1), 45-56.

Gable, F.J., J.H. Gentile, and D.G. Aubrey, 1990. Global Climatic Issues in the Coastal Wider Caribbean Region. Environmental Conservation, 17 (1), 51-60.

Giese, G.S. and D.G. Aubrey, 1987. Losing Coastal Upland to Relative Sea-Level Rise: 3 Scenarios for Massachusetts. Oceanus, 30 (3), 16-22. 
Gray, W.M., 1990. Strong Association Between West African Rainfall and U.S. Landfall of Intense Hurricanes. Science, 249, 1251-1256.

Hall, M. J., R. S. Young, E. R. Thieler, R. D. Priddy and O. H. Pilkey, Jr., 1990. Shoreline Response to Hurricane Hugo. Journal of Coastal Research, 6 (1), 211-221.

Hamann, R. and J. Wade, 1990. Mitigation of Hurricane Losses: Federal, State and Local Programs. Florida Sea Grant Project Number R/C-P-11 Report No. 100, 231pp.

Haney, J. C. , 1990. Interim Progress Report on 1989 Rapid Response - Hurricane Hugo Project: "Impact of Hurricane Hugo on Endangered Species of Marine and Endemic Forest Birds in the Lesser Antilles". Unpublished Trip Report, Woods Hole Oceanographic Institution, Woods Hole, Massachusetts, USA.

Haney, J.C., J.M. Wunderle and W.J. Arendt, 1991. Some Initial Effects of Hurricane Hugo on Endangered and Endemic Species of West Indian Birds. American Birds, 45 (2), 234-236.

Hubbert, G.D., G.J. Holland, L.M.Leslie and M.J. Manton, 1991. A Real-Time System For Forecasting Tropical Cyclone Storm Surges. Weather and Forecasting, 6 (1), 86-97.

Kaufman, L. S., 1983. Effects of Hurricane Allen on Reef Fish Assemblages Near Discovery Bay, Jamaica. Coral Reefs, 2 (1), 43-47.

Kesling, C. A., 1990. Preliminary Report: Effects of Hurricane Hugo on the Benthic Coral Reef Community of Salt River Submarine Canyon, St. Croix, U.S. Virgin Islands. In: Diving For Science...1990, The Proceedings of the American Academy of Underwater Sciences Tenth Annual Scientific Diving Symposium, Jaap, W.C. (ed.), 239-254.

Knowlton, N., J.C. Lang and B.D. Keller, 1990. Case Study of Natural Population Collapse: Post-Hurricane Predation on Jamaican Staghorn Corals. Smithsonian Contributions to the Marine Sciences, No. 31, 25pp.

Lobel, P. S., D. M. Anderson, and M. Durand-Clement, 1988. Assessment of Ciguatera Dinoflagellate Populations: Sample Variability and Algal Substrate Selection. Biological Bulletin, 175, 94-101.

Reading, A.J., 1990. Caribbean Tropical Storm Activity Over the Past Four Centuries, International Journal of Climatology, 10 (4), 365-376.

Roberts, L., 1990. Warm Waters, Bleached Corals. Science, 250, 213.

Rogers, C. S., T. H. Suchanek, and F. A. Pecora, 1982. Effects of Hurricanes David and Frederic (1979) on Shallow Acropora Palmata Reef Communities: St. Croix, U.S. Virgin Island. Bulletin of Marine Science, 32 (2), 523-548.

Rogers, C., 1989. Preliminary Assessment of Damage to Natural Resources in Virgin Islands National Park form Hurricane Hugo 9/18/90. Unpublished Trip Report, U.S. National Park Service, USVI, 3pp.

Sanford, T. B., P. G. Black, J. R. Haustein, J. W. Feeney, G. Z. Forristall, and J. F. Price, 1987. Ocean Response to a Hurricane. Part I: Observations.

Seymour, R. J. and D. Castel, 1987. Sealevel Changes Associated with Hurricane "Gloria". Ocean Engineering, 14 (1), 79-81. 
Sheets, R. C., 1990. The National Hurricane Center - Past, Present, and Future. Weather and Forecasting, 5 (2), 185-232.

Thieler, E. R., D. M. Bush and O. H. Pilkey, Jr., 1989. Shoreline Response to Hurricane Gilbert: Lessons for Coastal Management. In: Proceedings of Coastal Zone '89. Vol. 1, pp.765-775.

U.S. Army Corps of Engineers, 1971. National Shoreline Study, Appendix H, 14pp.

Wanless, H. R., K. M. Tyrrell, L. P. Tedesco, J. J. Dravis, 1988b. Tidal-Flat Sedimentation From Hurricane Kate, Caicos Platform, British West Indies. Journal of Sedimentary Petrology, 58 (4), 724-738.

Wanless, H. R., L. P. Tedesco, and K. M. Tyrrell, 1988a. Production of Subtidal Tubular and Surficial Tempestites by Hurricane Kate, Caicos Platform, British West Indies. Journal of Sedimentary Petrology, 58 (4), 739-750.

Wood, W.L., 1990. Coastal Management Alternatives for Reducing Storm Impacts at a Coast. Shore and Beach, 58 (4), 72-74.

Woodley, J. D. and others (19), 1981. Hurricane Allen's Impact on Jamaican Coral Reefs. Science, 214, 749-755.

Woodley, J. D., 1980. Hurricane Allen Destroys Jamaican Coral Reefs. Nature, 287 (5781), 387. 







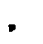


March 11, 1991

\section{Distribution List for Technical Report Exchange}

Attn: Stella Sanchez-Wade

Documents Section

Scripps Institution of Oceanography

Library, Mail Code C-075C

La Jolla, CA 92093

Hancock Library of Biology \& Oceanography

Alan Hancock Laboratory

University of Southern California

University Park

Los Angeles, CA 90089-0371

Gifts \& Exchanges

Library

Bedford Institute of Oceanography

P.O. Box 1006

Dartmouth, NS, B2Y 4A2, CANADA

Office of the International

Ice Patrol

c/o Coast Guard R \& D Center

Avery Point

Groton, CT 06340

NOAA/EDIS Miami Library Center

4301 Rickenbacker Causeway

Miami, FL 33149

Library

Skidaway Institute of Oceanography

P.O. Box 13687

Savannah, GA 31416

Institute of Geophysics

University of Hawaii

Library Room 252

2525 Correa Road

Honolulu, HI 96822

Marine Resources Information Center

Building E38-320

MIT

Cambridge, MA 02139

Library

Lamont-Doherty Geological

Observatory

Columbia University

Palisades, NY 10964

Library

Seriais Department

Oregon State University

Corvallis, OR 97331
Pell Marine Science Library

University of Rhode Island

Narragansett Bay Campus

Narragansett, RI 02882

Working Collection

Texas A\&M University

Dept. of Oceanography

College Station, TX 77843

Library

Virginia Institute of Marine Science

Gloucester Point, VA 23062

Fisheries-Oceanography Library

151 Oceanography Teaching Bldg.

University of Washington

Seattle, WA 98195

Library

R.S.M.A.S.

University of Miami

4600 Rickenbacker Causeway

Miami, FL 33149

Maury Oceanographic Library

Naval Oceanographic Office

Stennis Space Center

NSTL, MS 39522-5001

Marine Sciences Collection

Mayaguez Campus Library

University of Puerto Rico

Mayaguez, Puerto Rico 00708

Library

Institute of Oceanographic Sciences

Deacon Laboratory

Wormley, Godalming

Surrey GU8 5UB

UNITED KINGDOM

The Librarian

CSIRO Marine Laboratories

G.P.O. Box 1538

Hobart, Tasmania

AUSTRALIA 7001

Library

Proudman Oceanographic Laboratory

Bidston Observatory

Birkenhead

Merseyside L43 7 RA

UNITED KINGDOM 



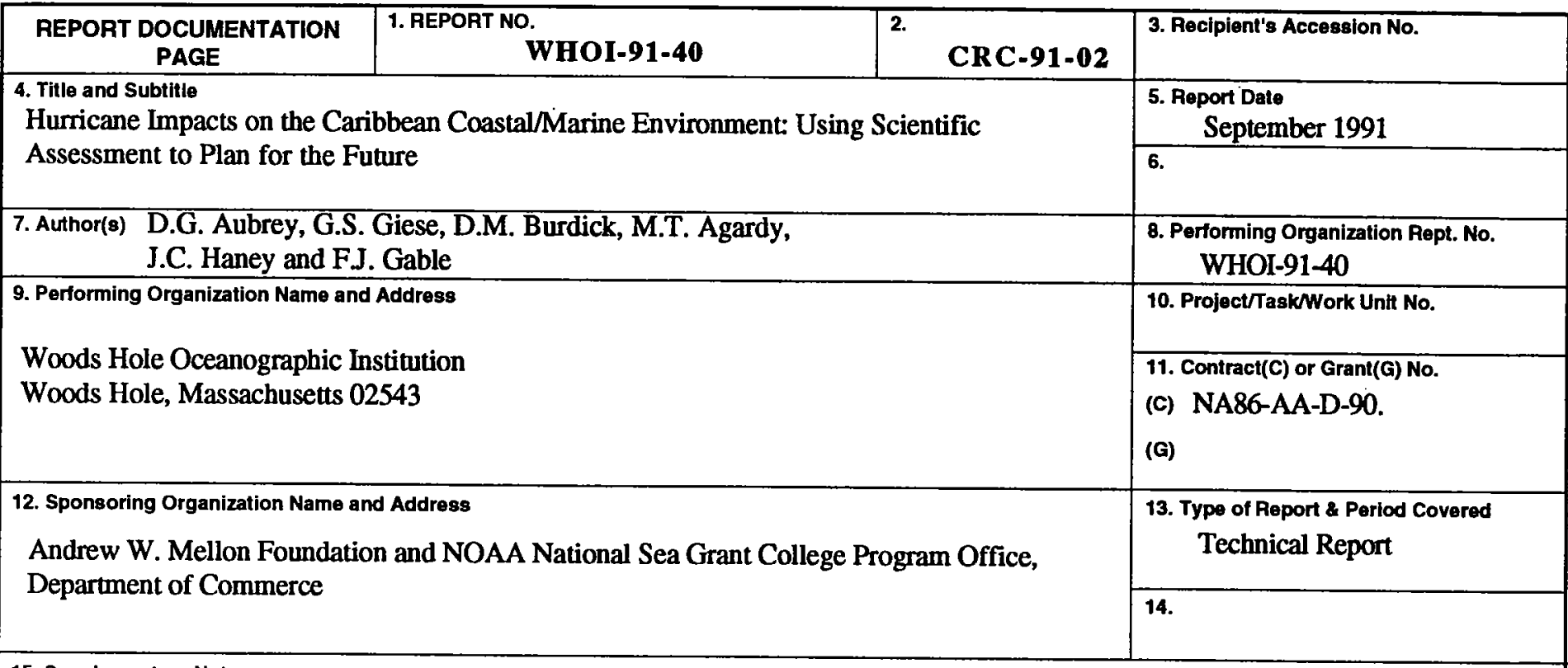

15. Supplementary Notes

This report should be cited as: Woods Hole Oceanographic Inst. Tech. Rept., WHOI 91-40, CRC-91-02.

16. Abstract (Limit: 200 words)

The passage of Hurricane Hugo through the eastern Caribbean provided a unique opportunity for multidisciplinary study of (1) the effects of severe storms on tropical coastal and marine ecosystems, and (2) the physical and biological responses of those ecosystems to intense storm-induced changes. In addition to its direct value as basic science, this study can be used to facilitate development of improved coastal and marine resource management capabilities.

17. Document Analysis a. Descriptors

resource management

scientific assessment

hurricanes

b. Identifiers/Open-Ended Terms

c. COSATI Field/Group

18. Availability Statement

Approved for public release; distribution unlimited.

$$
\begin{gathered}
\text { 19. Security Class (This Report) } \\
\text { UNCLASSIFIED }
\end{gathered}
$$

20. Security Class (This Page)
21. No. of Pages 57

22. Price 
